\title{
Spatial Representations of Ideology and Politics In Urban Scene: Keçiören Example
}

\author{
İdeoloji ve Politikanın Mekânsal Gösterimi: Keçiören Örneği
}

\section{İrem ÖZ}

Şehir Plancisı

irem.oz88@gmail.com

\begin{abstract}
Being the capital city of a newly established Turkish Republic that was descended from the Ottoman Empire, Ankara was attributed a massive symbolic meaning. Ankara became the representative of a new Turkish State that aimed to attain a place in the global picture as being a modern and secular nation state. It carries a distinct characteristic as the reflections of transformations taking place in the political sphere can be read from the urban space. In this context, Keçiören District, being one of the largest and most populated districts of Ankara has undergone a massive transformation after 1994 with the change in the political structure.

The aim of this study is to make an analysis of the transformation that has been taking place in Keçiören district of Ankara since 1994, focusing on the architecture of AKP government that has been taking place not only in the architectural or urban field but also in the political, social, economic and cultural fields. What has been tried to be analyzed in this study is the emergence of a new architectural style that imitates the past with a modern approach not only in terms of urban and architectural quality but also from social and political motives that are embedded in the "culture" by using Pierre Bourdieu's sociological notions as elements of interpretation.
\end{abstract}

Keywords: Ankara, Keçiören, Urban transformation, Political transformation, Historicism, Eclecticism, Pierre Bourdieu

\section{Öz}

Osmanlı Dönemi’ni takiben kurulmuş olan Türkiye Cumhuriyeti’nin başkenti olan Ankara’ya bu bağlamda önemli sembolik anlamlar yüklenmiştir. Modern Türk Cumhuriyeti’nin temsili olan Ankara kenti, modern ve laik bir devlet olarak küresel tabloda yer edinmeyi amaçlamıştır. Diğer şehirlerden farklı olarak, siyasi alanın merkezinde olması sebebiyle, siyasi alanda olan dönüşümleri mekân üzerinden okumak mümkündür. Bu bağlamda, Ankara’nın en büyük ve nüfusu en fazla olan ilçelerinden Keçiören 1994 yılı sonrası siyasi sahada olan dönüşümler sonucunda tamamen değişmiştir.

Bu çalışmanın amacı, Ankara’nın Keçiören ilçesinde 1994 yılı sonrası başlayan ve hâlâ devam eden dönüşümü incelemektir. AK Parti mimarisinin üzerinde durularak bu dönüşümün etrafında sosyal, politik, kültürel ve ekonomik sahalarda meydana gelen değişimler incelenecektir. Bu çalışma ile amaçlanan, geçmişi sadece fiziksel olarak değil, bunlar ile iç içe geçmiş sosyal ve siyasi olarak da benimsemiş yeni bir mimari oluşumun incelemesini Pierre Bourdieu'nun sosyolojik kavramları ile yapmaktır.

Anahtar sözcükler: Ankara, Keçiören, Kentsel dönüşüm, Politik dönüşüm, Tarihselcilik, Seçmecilik, Pierre Bourdieu

\footnotetext{
* This paper is based on the Master's Thesis study "Reuse od Traditional Architectural Elements in Modern Keçiören" supervised by Prof. Dr. Filiz Yenișehirlioğlu, Koç University, Institute of Social Sciences.
} 


\section{Introduction}

Ankara had been subjected to numerous development plans after becoming the capital city of the Turkish Republic. A controlled growth and a planned urbanization were sought so that Ankara would become the representation of modern identity. The urbanization process in Ankara was planned up until 1950s, when the vast migration wave from the rural areas to the urban areas caused by the modernization in agricultural production threw off the balance established by the efforts of early Republicans. Many people were moving from the rural areas to Ankara, however, the city did not have sufficient space to support the settlement of this unplanned population. The migrants found their own solution to this issue with the construction of illegal housing areas in the peripheral areas of the city. A point worth mentioning here is the fact that the hinterland of the city covered a much smaller area back then; therefore, the areas that can be considered as central areas within the city today were regarded as peripheries.

Keçiören in this context became one of the main areas of these illegal, low-density housing settlements referred to as "gecekondu." By 1994, a political party infamous for its nationalist political stance became the dominant power in the district. The result of the elections in 1994 stands as a milestone in the history of Keçiören as it started the process of urban transformation on the basis of political ideology. This transformation that has been taking place since 1994 constitutes the scope of this research. In this study I aim to make an analysis of the transformation not only in terms of architecture but also in terms of political and social processes. In the course of this study I will provide an academic backdrop to understand the social and political dynamics embedded in the physical transformation process that has been taking place in Keçiören district, making an emphasis on the period after 1994 which resulted in the emergence of an eclectic architectural style. In order to strengthen the bonds among a society and to gather them around an ideology based on nationalism and/or Islamism, the politicians started to use certain symbols and icons. The use of these symbols or icons alone or together in an eclectic manner and mimicking certain architectural styles of the past without proper academic research or professional consultancy leads to a chaotic situation in the urban and social fabric. The aesthetic quality in the area is reduced to the presence of these historical Ottoman/Seljuk elements as decoration elements. With this study I aim to provide the social and political dimensions of the process.
In order to attain this, Pierre Bourdieu's concepts were used.

\section{Sociology of Bourdieu}

"Taste classifies, and it classifies the classifier." (Bourdieu, 1984).

In order to understand and explain the taste, culture and social status of the people living in the Keçiören area, significant frameworks and terminology created by Pierre Bourdieu were utilized. Bourdieu's work is important in this context as his model constructs a theoretical model of social practice, carrying the field of sociology a step forward and trying to scientifically explain what people do in their daily lives (Jenkins, 2002, pp. 67-68).

The reason why a Bourdieusian approach was used was to construct the theoretical framework of this study is because Bourdieu, in his work Distinction (1984) analyses societal dynamics based on the judgment of taste and aesthetics and how these phenomena lead to distinction among different groups (or classes) within the society. As a different stance from previous academic research that was conducted on the subject and evaluate the process based on the physical and aesthetic quality of the district, was taken the aim of the research was to conduct an analysis of the problem based on the social, cultural, and political dynamics that lead to the transformation of aesthetic judgment, therefore, the transformation of physicality

\section{Key Concepts by Bourdieu:}

\section{Habitus, Field and Capital}

In his research about social practices, Bourdieu's concern is the question of what individuals do in their daily lives. $\mathrm{He}$ indicates that, individuals have to deal with a set of social positions that are constrained by a relation of homology to a series of relationally characterized activities (Bourdieu, 1996, p. 10). On the other hand, his idea of the complexity of social life and how it cannot be merely understood by the aggregate of individual behavior; and the rejection of simplification of practice to individual decision making or its determination via supra-individual structures, drove him to fill the explanatory gap between two extremes. In order to establish a bridge between those two extremes, he came up with the notion of habitus (Jenkins, 2002, p. 74).

Habitus is explained as "an acquired system of generative schemes objectively adjusted to the particular conditions in which it is constituted" (Bourdieu, 1977, p. 95). In simpler 
terms, it is described as the values, and dispositions gained from ones cultural history that usually stays with one context as they are durable and transposable. These values and dispositions channel us to respond to cultural rules and contexts in different ways which are determined by where or who we have been in a culture (Webb, Schirato and Danaher, 2002, pp. 36-37). Habitus is created in an individual's placement in the social structure. When an individual internalizes the social structure and his/her place in it, which takes place unconsciously during the early childhood, the individual determines the possibilities and impossibilities in the life and develops aspirations and practices accordingly (2002, p. 46).

Bourdieu defines this relationship between the class structure and habitus by saying that "A social class - a class of identical or similar conditions of existence and conditionings, is at the same time a class of biological individuals having the same habitus, understood as a system of dispositions common to all products of the same conditioning" (Bourdieu, 1990, p. 59 in Rey, 2007 p. 50). So once an individuals' habitus is developed it is always a class-ed habitus which causes the agent to perceive, appreciate and act with respect to dispositions of the existing class and contribute to his/her habitus formation. Therefore identity is the key deterministic influence on habitus (Rey, 2007, p. 59). Following this notion that social subjects are structured by the habitus, Bourdieu (1990, p. 297) also suggests that culture (and aesthetic judgment and taste) is socially structured; he says that "the struggle for taste is a struggle for power".

Before going further on with the social reproduction of culture, another concept should be described in order to understand the context established by Bourdieu. He uses the term field to describe "a structured place of special forces and struggle" (Bourdieu and Wacquant, 1992, p. 243). He further explains the concept as being a structured social space, a force-field which includes the people who dominate and people who are dominated. In this space, operation of various constant relationship of inequality is expressed through a struggle between various actors for transformation/preservation of the field. All the agents use their various kinds of power (capital) to compete in this field. With the possession of this power, the positions (and the strategies) of the agents within the field are defined (Lingard and Christie, 2003, p. 322). It is described as being a social arena where struggles or actions take place over specific resources or stakes and access to them. Fields are defined by the stakes that are at stake such as goods, housing, intellectual knowledge, education, employment, land, political power, social class, prestige, taste, etc... (Jenkins, 2002, p. 84). These stakes that are at stake can be defined as the types of capital in the field. And the struggle is over these kinds of capital while the actions are comprised of the production/consumption of the capital and positioning for positions among the consumers of the capital (agents) (Rey, 2007, p. 44).

In a social sphere with many dimensions where habitus is the dispositions and cognitions and field is the arena agents seek to maintain or improve their social status, capital stands for the currency which enable agents to gain social recognition (Allen and Anderson, 1994). In Bourdieu's own words; "capital is a social relation ... which only exists and only produces its effects in the field in which it is produced and reproduced" (1989, p. 113).

Capitals are important as they help us to understand the major differences among agents and groups that is reflected as conflict and struggle in the social sphere (Poyraz, 2011, p. 32). Capital should not be only comprehended as an economical tool; it also applies to the resources like status, power, personal contacts and formal/informal forms of knowledge (Hiller and Rooksby, 2005, p. 24).

Bourdieu identifies three main types of capital; economic, social and cultural capital and makes an emphasis on the importance of symbolic capital. Bourdieu gives definitions of different kinds of capital claiming that capital presents itself in three fundamental forms depending on the field it functions: economic capital which can be directly converted into money and can be institutionalized as property; cultural capital which can transform into economical capital under certain conditions and can be institutionalized as educational qualifications and the social capital consisting of social obligations and relationships that can be converted into economic capital in certain cases and that can be institutionalized as the titles (1986, p. 47).

Bourdeiu also makes an emphasis on the importance of symbolic capital. Hillier and Rooksby (2005, p. 24) explains the cultural capital by relating it to prestige status which includes resources such as articulateness, aesthetic preferences and cultural awareness. It is simply the combination of tastes, beliefs, values, skills and knowledge that were acquired in formal or informal ways. Bourdieu explains how cultural capital is acquired by saying "cultural capital can be acquired, to a varying extent, depending on the period, the society, and the social class, in the absence of any de- 
liberate inculcation, and therefore quite unconsciously" (1986, pp. 48-49). Simply, it can be described as the capacity to play the cultural game, to know what and how to approve and to disapprove, to have internalized the necessary tools to have a taste of the appropriate art (Blunden, 2004).

Cultural capital is of great importance in Bourdieu's work. Being the key form of the symbolic capital, cultural capital legitimates and reproduces social distinctions (Rey, 2007, p. 53). Bourdieu explains the concept of stratification in the society not only via the distribution of economic capital. Although not much importance has been given so far, the cultural consumption, taste, preferences and perception of aesthetics or cultural capital in other words strikes out as another component of reproduction of class and social inequality. The ones who possess larger amounts of economic and cultural capital become more dominant and will impose their hierarchy of taste and preferences on others.

As mentioned in the previously, symbolic capital is the key form of the cultural capital according to Bourdieu. Symbolic capital represents the form of the different kinds of capital when they are perceived and recognized as legitimate by incorporating three different kinds of capital (Hillier and Rooksby, 2005, p. 24).

Symbolic capital is highly related to the symbolic power, which takes its roots from the volume of symbolic capital (Bourdieu, 1989, p. 23). Bourdieu gives great importance to symbolic power, by his words symbolic power is "A power to preserve or to transform objective principles of union and separation, of marriage and divorce, of association and dissociation, which are at work in the social world; the power to conserve or to transform current classifications in matters of gender, nation, region, age, and social status, and this through the words used to designate or to describe individuals, groups or institutions. To change the world, one has to change the ways of world-making, that is, the vision of the world and the practical operations by which groups are produced and reproduced (Bourdieu, 1989, pp. 22-23).

In the context of the symbolic capital, objects can be described as the abstract reflections of their environment and can have symbolic capital values. Representing the environment's cultural value by being the symbolic representations of them, this symbolic capital can be found embedded in the physical space. Urban landmarks become significant in an environment as they carry a symbolic val- ue representing cultural and in Keçiören an example for the political stances that provide certain prestige to their environment. Keçiören area, possessing various landmarks is an example case study where a cultural image is imposed as a result of the changing political field.

To sum up Bourdieu suggests that, every individual occupies a position in society's different fields, which is objectively determined by the amount of capital he/she possess (Rey, 2007, p. 44). Following this, agents who possess various dispositions and volumes of capital, access to the field so that they can seek their rights and profits. Preservation of the already possessed and transformation to acquire more are appeared to construct the core of the struggles among agents and institutions (Poyraz, 2011, p. 30).

Forms of capital can be viewed as weapons and resources that can determine and consolidate the individuals' position in the social space as the more capital an individual has the more resources they possess in order to adopt themselves to the changing circumstances and to strengthen their position (Bourdieu, 1998 in Poyraz, 2011, p. 33). On the other hand, this statement does not mean that every kind of capital is valid under distinct conditions. Different types of fields require different forms of capital (Poyraz, 2011, p. 33).

Taking this statement a step forward, Bourdieu suggests that agents in the possession of similar types of capital gets together and forms groups in the physical and social space as a result of the need to dominate the space $(1989, \mathrm{p} .17)$. He says that "... capital makes it possible to keep undesirable persons and things at a distance at the same time that it brings closer desirable persons and things" (Bourdieu, 1999, p. 127). To conclude, if an agent desires to enter a field, he/she has to meet the certain form of capital requirement that field requires and that would satisfy the dominant agents' expectations. This process constitutes the core of the inclusion and exclusion mechanisms in social and physical space. In order to survive in a certain field, the agents (especially the disadvantaged ones) try to preserve or increase the volume of capital they are in possession of.

\section{Cultural Field and Judgment of Taste}

Culture in sociological terms is a peculiar form of life that is produced and reproduced by a group of agents. It expresses various meanings not only in the field of art and learning but also in institutions of ordinary behavior. In aesthetic terms, it signifies the human expression of cre- 
ativity. In other words agents attribute meaning to the world by using the expressive power of artistic creation (Susen, 2011, pp. 174-175).

Bourdieu claims that culture is a game of distinction in which class differences are also expressed or visibly established for the first time (Joas and Knöbl, 2011, p. 26).

"People compete about culture and they compete with it" (Jenkins, 1992, p. 128). Cultural field is defined as a series of institutions, rules, rituals, conventions, categories, designations, appointments and titles that constitute an objective hierarchical system while producing certain discourses and activities. Bourdieu suggests that cultural fields are not static, but rather dynamic and fluid as they are composed of institutions and rules and interactions between them. Cultural capital is not stable or universally accepted, what makes it interesting might not be acceptable in another cultural field (Webb, Schirato and Danaher, 2002, p. 22).

Bourdieu suggests that the legitimacy of a particular activity within various cultural fields is determined by the ruling class. For example, the ruling class declares avantgarde art to be real art, when they require a level of distinction, but just when lower class starts to appreciate and appropriate this style, the fashion ends (Joas and Knöbl, 2011, p. 27). Following this, Bourdieu extends his thesis about the notion of habitus that is acquired within a particular class, defines the life-style by distancing themselves from the other classes culturally. Occurrence of various types of lifestyles found within a society is entailed by symbolic conflicts over the efforts made by different classes to achieve distinction (Joas and Knöbl, 2011, p. 27).

Susen sums Bourdieu's theory by saying that as cultural relations are nested in material relations just like material relations are embedded in cultural relations, the fact that every society produces its own cultural economy should be recognized. Following this, the formation of social classes follows the societies' capacity to reproduce via cultural differentiation. It is not possible to conceive the material power of class relations without taking into account the symbolic power of cultural relations (2011, p. 176).

Just like any form of capital, cultural capital can be transformed into a tool of social domination. Culture, being a vehicle for class domination serves as both an instrument and a source of power. Using culture for domination is subtle but it penetrates every sphere of society much more efficiently than any other form of capital. (Susen, 2011, p. 194). Symbolic domination serves as the key to the cultural domination. "The power of culture is only conceivable as symbolic power" (Bourdieu, 1992). This symbolic power is not rooted from the material substance form but from its social significance. When a commodity carries a symbolic power, the main aim for the individual becomes, is to acquire the value that commodity represents and the authority that commodity contains (Susen, 2011, p. 180).

Bourdieu aims to prove that aesthetic judgment, being part of the culture is socially determined as well. The aesthetic theory that claims to be great music, literature or architecture, is in reality just a perception form that is derived from specific social and economic realities (Joas and Knöbl, 2011, p. 27). Webster makes an emphasis on the social construction of aesthetic codes. Art and cultural consumption are predisposed, consciously and deliberately or not to fulfill a social function of legitimating social differences (Webster, 2011, p. 51).

Taste being the representation of hidden exercise of power; is a 'matter of course', a natural difference distinct from what is social. It is a battlefield in cultural reproduction and legitimating of power (Rahkonen, 2011, p. 126). As stated above, the dominant class in the cultural field aims to distance itself from the others by distinction; by producing goods of pure taste, high-brow culture, and the products of field of restricted production. This way the high class distinguishes itself from the other groups representing other categories (Rahkonen, 2011, p. 127). This distinction is also represented in physical space. There is a tendency for agents that are close together in social space to find each other by choice or necessity, to form groups in geographical space (some exceptions may occur) (Bourdieu, 1989, p. 16). Although cultural field was represented as a divisive structure that would divide us into groups as the ones with the taste and others, it has a unifying dimension. It also produces the unifying symbol of us, through symbolic power, which is used especially by governments to create a sense of the national community (Webb, Schirato and Danaher, 2002, p. 156).

In conclusion, Bourdieu's notions of class structure and social reproduction of culture can be applicable to Keçiören in many dimensions. The following sections that provides a historical context aims for the understanding of class formation in Ankara and social background of the residents that are living within the area of the case study; Keçiören. 


\section{Historical Background}

Having a history of more than three thousand years, it may be said that Ankara is one of the oldest cities in Anatolia. Situated upon a steep hill above the plain on the Enguri Su, a tributary of Sakarya River, Ankara has always been an important center for numerous civilizations from ancient times till to the present. In particular, Ankara's strategic and geographic location has given the city many advantages over the course of its history (Kaya, 2002). For the scope of this research the time period starting with the establishment of the Turkish Republic with an emphasis on the period after 1980s will be used.

Before becoming the capital city of Turkey, Ankara had lost its former importance being an important Anatolian town located in a strategically advantageous location with the outbreak of the First World War which destroyed a broad area. The city started to regain its former importance when it became the administrative center for the Kemalist forces due to its central location, allowing it to exert control over much of Anatolia (Tekeli, 1982). In 1923, after the establishment of the Turkish Republic, the capital city was moved from Istanbul to Ankara in order to locate the capital in a more central location.

Mustafa Kemal, being the president, intended for the new capital to be a symbol of modernization. As a part of the modernization process, Ankara was designed to be a very modern city and it is the first planned city of the Republic Era that was planned to have wide boulevards and many green areas. The city rapidly grew and became one of the major urban centers in Turkey (Derieu, 2013).

\section{Spatial Development and Social}

\section{Transformation of Ankara}

In order to understand the urbanization process after it became the capital city and the transformation of the city to what it is today, I am going to study the history of Ankara in 3 developmental phases.

The first one, which Şengül refers to as the "Urbanization of the Nation State," was the period from 1923 to the 1950s.Briefly, this period can be seen as reflecting the transition from a land order with its roots in the centuries-long Imperial Ottoman domination of Anatolia, to an order centered on the nation-state. The socio-spatial order of this period reflects a radical transformation as the patterns of land ownership of the previous phase and the new urban stratification show vast differences. Although there is a radical transformation, this period cannot be described as a disengagement from the previous one as the transformation had started in the Ottoman Period (2001, pp. 103-104).

This period was defined by the efforts of constructing a new republic, socially and spatially. In this period of change, there existed a conflict between the Ottoman Empire's socio-spatial structure and the newly established republic's ideologies. As Şengül acknowledges, the Ottoman Empire had a strategy to expand its territory, the concept of "motherland" was never taken into consideration. On the other hand, when Ankara was declared the capital city, the main priority was to create the feeling of a "motherland" in Anatolia (Şengül, 2001).In this socially and economically distinctive period, a new architectural style representing the contemporary ideologies emerged. This nationalistic architectural style had a broad effect on the future of architecture which continues even be today.

The second period, called the "Urbanization of Labor," established a new layer of socio-spatial relations. Following the Second World War (1939-1945), there can be seen a vast migration from rural areas to urban areas. At the beginning of this period the migration from rural to urban areas caused many problems, however the relationship turned out to be a complementary one as time progressed. The relationship was problematic as the process of modernization was interrupted by the new low-income class that had migrated from the rural areas. The low-income group created their own socio-spatial structures contradicting the social structure that had been envisioned in the previous period. After a period of contradictions and bargaining, this new socio-spatial structure became complimentary to the intended structure (Şengül, 2001, p. 104).

The Yücel-Uybadin Plan aimed to create a dense and homogeneous city; therefore it brought restrictions and regulations. One of the most important regulatory decisions included in the scope of the plan was about restricting new developments in order to plan boundaries. The restricted development within the borders of the municipality resulted in a drastic increase in land prices, thereby encouraging unauthorized construction in areas the low-income, newly-migrated families could afford. These squatter areas (gecekondu) around the main arteries formed the fringes of the city until late 1970s (Çalışkan, 2009)

At first, the "gecekondu" problem was not seen as an issue that needed to be immediately addressed. It was seen 
as a self-supply method of answering the need for housing (Günay, 2006). In the mid 1970s, by the time socially reproduced gecekondu became a part of the dual organization of the city, it began to be seen as a major problem (Tucaltan, 2008). It can be concluded that the migration from rural areas to urban areas created the conditions necessary for the social division between labor and highincome classes to be reflected in the stratification of the urban landscape.

The main gecekondu areas in the city were concentrated around Altındağ, Yenidoğan and Kayaş. The migrant population was geographically distributed in the city according to where they came from, thereby forming their own communities (Tuçaltan, 2008). In this period, Keçiören appears to have become a component of the urban scene. These rapid urbanization processes caused the formation of gecekondu areas in Keçiören as well.

By the end of this period, Ankara was occupied by two different groups; the middle-high income groups shaped by the Yücel-Uybadin Plan and the low income groups shaped organically around those areas (Günay, 2006). The Yücel-Uybadin Plan did not satisfy the need for a planned development form for the gecekondu areas due to the fact that regulations concerning gecekondu were not in accordance with the upper scale plan; they were just temporary solutions to the growing problem (Turan, 2007).

The last period is named as the "Urbanization of the Capital". Although the urbanization of the capital had been an ongoing process throughout the previous periods, in the last 30 years, the capital became a hegemonic element as it became increasingly dominant over many spheres of life (Şengül, 2001, p. 105).

In this period the city started to lose its characteristics as being a complementary unit. As a characteristic of the capitalist economy, the middle class started to be dissolved while the rich became richer and poor became poorer. This duality spatially showed itself as a stratified urban fabric (Ataöv and Osmay, 2007, p. 67). The low-income group moved to other parts of the city, creating communities which led to social and spatial conflict with the rest (Uzun, 2005).

In this period planning decisions that address gecekondu issue transformed parts of the city. Although not in its entirety, some of the land provided by the clearance of gecekondu areas was used for mass housing projects as new residential areas at the periphery of the cities (Özden, 2002). Places like Keçiören which were excluded from the Yücel-Uybadin plan, started to be integrated to the city (Günay, 2006).

In 1994, with the local elections, a new administration run by a conservative party, Refah Partisi (RP), came to power both in some important localities and the Greater Municipality of Ankara. This new local government had a different construction based approach. The most comprehensive transformations and improvements took place in the Keçiören area (Tuçaltan, 2008).

In this period the nature of the socio-economical classes had changed as well. It was no longer composed of unskilled migrants but the new middle class (Ataöv and Osmay, 2007). In order to provide new housing and improve the existing housing conditions, new large scale transformation plans as well as ongoing privatization policies were implemented (Tekeli, 2005).

In 2003, with the general elections, Adalet ve Kalkınma Partisi (AKP) came into the power. With the AK Parti's rise to power, 2004 stands as a milestone in the political history of Ankara. New laws were designed and passed in order to enable the implementation of transformation projects which include the wide scale North Ankara Transformation Project ${ }^{1}$. More than 40 transformation projects all over Ankara were prepared (Akın, 2007). Keçiören became an area which has changed completely from a gecekondu settlement area into an urban settlement that was viewed as one of the best examples of AK Parti government policy.

Tuçaltan (2008) criticizes the Turkish Government's approach towards transformation as being insensitive to urban issues and urban planning. Gecekondu clearance or improvement was used as an excuse for building luxury high-rise buildings, gated communities, and shopping malls in the name of urban regeneration.

To sum up, Şenyapılı (2004) concludes that 1950-1980 is the period when most of the social and economic problems (both in micro and macro level) emerged. A foreigndependent economic development is the reason why both rural and urban populations are facing so many social problems.

For the Ankara case, between 1950 and 1980 the urban population of Ankara increased 12 times (Kartal, 1982). Kartal further explains the migration process by pointing out its difference from the urbanization process. He 
claims that the recently migrated rural population becomes the urban population after a period of time. As the new migrants do not know the city they migrated to, they move to the places where they are close to their relatives and acquaintances. In a few years' time they create their own local communities without being assimilated to the urban culture (1982). Living in those communities which are bound by symbolic relations, the migrant population distance themselves from urban life by pursuing their rural life-style in an urban environment, usually in squatter areas in the case of Ankara (Baştuğ, 1979). The conservative regime that came into the power after the 1980s used architecture to provide symbols from the past that would gather the migrant population under a sense of identity.

As the case study to be analyzed in this article, the Keçiören district was once a squatter settlement area that drew a tremendous amount of migration from rural to urban areas and is an example of the reflection of the conservative rightist ideology on space. This was done on two levels. The first level is the elimination of republican modernism from the collective urban memory. This was done by the reestablishment of Ottoman and Seljuk elements in architecture (Elçin, 2008). On a societal level, it represents an identical formation that creates a feeling of "us and them", which causes the populations living in this area to have even tighter bonds on a societal level. Thus, they were provided with social bonds that they can hold on to psychologically and symbolic architecture that they can hold on to physically.

\section{Case Study: Keçiören Distric}

\section{History of Keçiören}

Keçiören, located approximately $3 \mathrm{~km}$ away from the city center, covers the northern portion of the city. It is the second largest district of Ankara covering a $190 \mathrm{~km} 2$ area with a population of 848.305 according to 2013 data (Barış, Uçkaç and Uslu, 2009 and TUIK). Today, Keçiören is divided into 50 local neighborhood units, mahalle the largest ones being Etlik, İvedik, Kalaba and Aktepe. (Mahalle/ Muhtar, n.d.).

Until the 1940s, before the rural-urban migration took place, Keçiören was a recreational area used during the summer where vineyards and orchards were found for centuries. In history, Keçiören is described as a small agricultural town with rural character (Pınarevli, 2005). (Figure 2)

According to the Jansen Plan (1932), the typical designs of the vineyards and gardens were to be protected. Up until the 1950s the district managed to preserve its characteris-

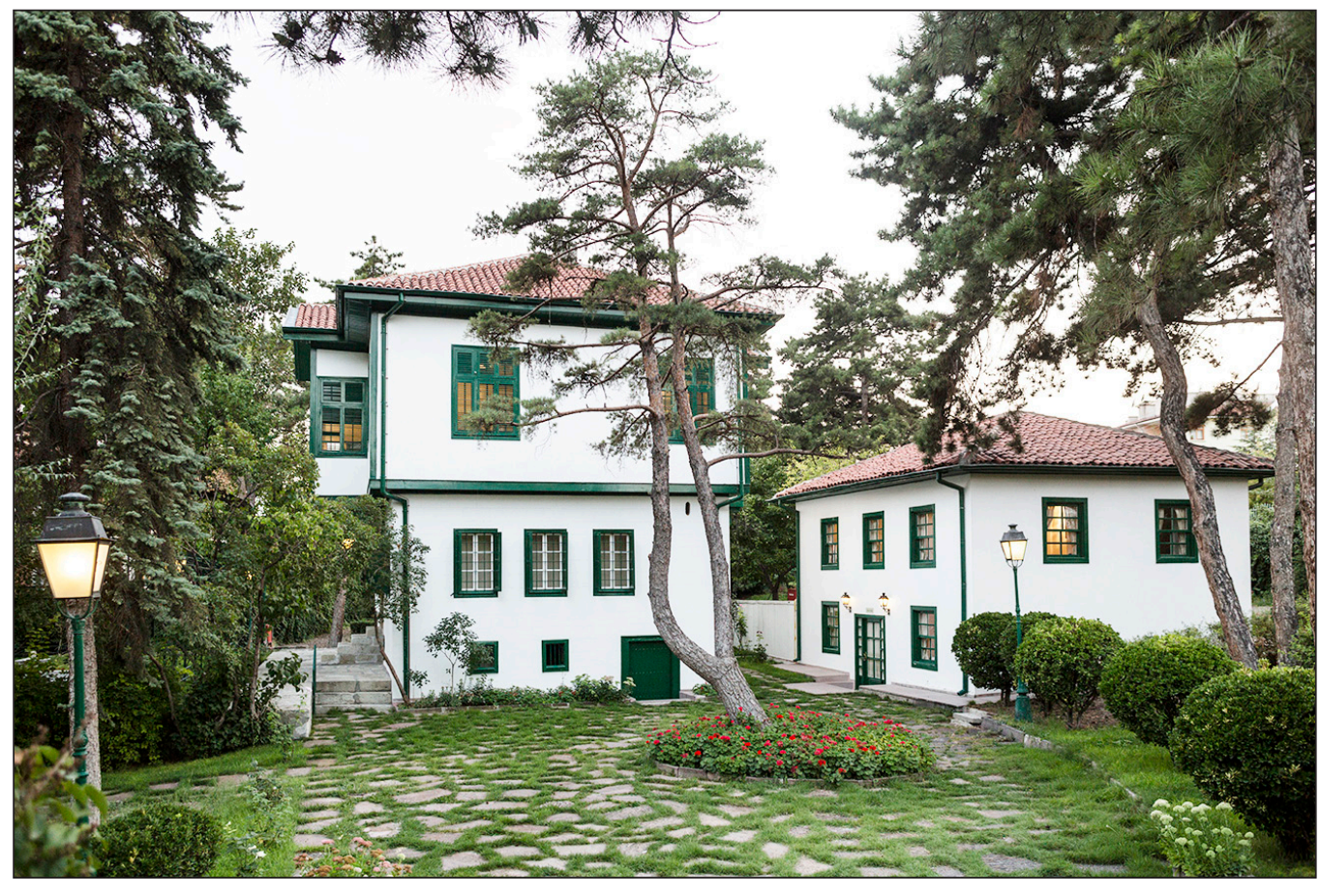

Figure 1. Koç University Vehbi Koç Ankara Studies Research Center (VEKAM): One of the last traditional vineyard houses in Keçiören. Source: VEKAM. 
tics. The Kalaba and Aktepe neighborhoods were the core of the district. During 1940s and 1950s many proposals for a higher density settlement were made, but most of them were rejected as they conflicted with the Jansen Plan strategies for the protection of the district's original character (Şenyapıl1, 2004).

The increasing migration from the rural to urban areas brought the need for more housing, but no solutions were proposed to resolve the issue. These low-income groups produced their own solution, since they were not able to find suitable housing, they produced "gecekondu". In the 1940s gecekondu did not cause any serious problems as they were usually concentrated around one area (Etlik today) and they were low-density. However, in the 1950s there occurred a rise in the number of gecekondu in Keçiören, but this shift was not enough to change the characteristic of the district (Şenyapilı, 2004). On the other hand, in some parts of Keçiören that are extensions of the city center, several housing zones were created by the government to control the rising population (Pinarevli, 2005). Towards the end of the 1950s, Yücel-Uybadin plan proposed new settlement areas around Keçiören. These areas were designed to sustain denser populations by using the system of blocks and parcels. Nonetheless, this new plan proposal did not contain any strategies to cope with the rising gecekondu problem (Şenyapıll, 2004).

In 1966, Keçiören became the part of Altındağ district. In 1970, with the preparation of the 1990 Ankara Plan, decentralization of the population from the inner city, which included Keçiören area, was proposed. For the first time, a proposal for the prevention of squatter settlements was made, however the scope of these prevention strategies did not cover all of the gecekondu zones (Figure 2) (Kalaycığlu, 2006).

After the 1960s the migration rate accelerated. Keçiören, once a district used mostly by governmental workers (memur), started to lose its original characteristics after the 1970s. Local tradesmen and gecekondu owners started to dominate the area. The migration caused the local population composed of Armenians, Romans, Jews, and Turks to dissolve and was replaced by a population that could be defined by its Alevi-Sunni characteristics (Kurtoğlu, 2004).

In 1984 Keçiören was declared a municipality district under the Ankara Metropolitan Municipality. This gave the Keçiören Municipality authority to make and implement 1/1000 scale construction improvement (Islah ve Imar Planı) plans especially for the gecekondu areas. The

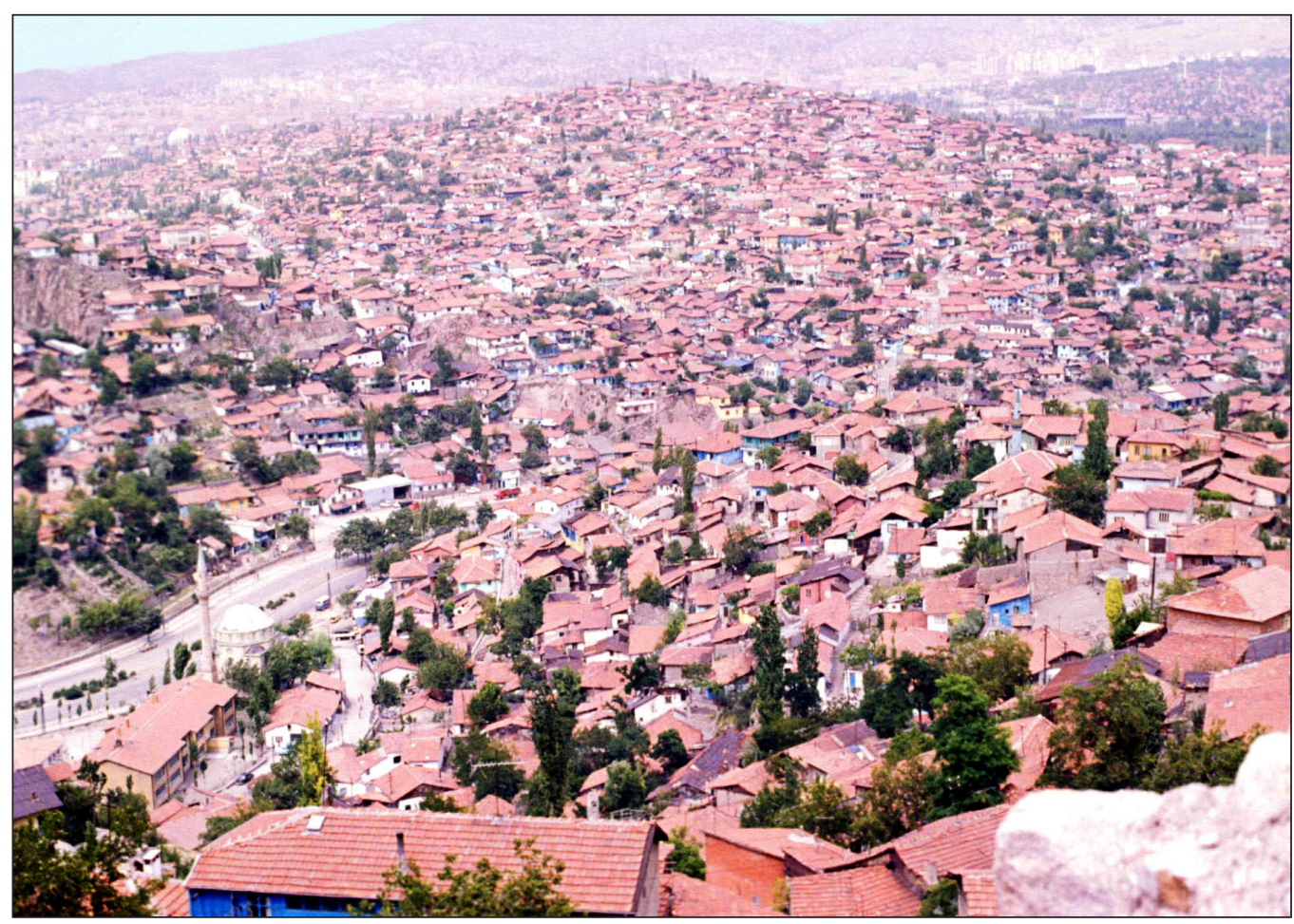

Figure 2. Typical Gecekondu Settlement. Source: Baykan Günay personal archive. 
completion of these plans took place in 2004, extending over a period of 20 years. With these plans, the density and social infrastructure of the area was reconsidered. The building density had been increased to 4-storey high apartment blocks and the social infrastructure to support them needed to be expanded. The physical form of Keçiören today is mostly created with the "Construction Improvement Plans" that were made between 1994 and 2004 (Kalaycıŏlu, 2006).

It can be concluded that the main deterioration of Keçiören started in the 1950s with the increased migration from the rural to urban areas. Up until the 1970s or even 1984 the area was left to its own devices, when the situation became irreversible. The local elections of 1994 represent a milestone in the history of Keçiören, as the change of the local government transformed the district politically and physically.

\section{Keçiören after 1994}

1994 was a very important turning point in the history of Keçiören as the Republican Identity of Ankara transformed into a conservative one that would change the face of Keçiören and create "Keçiörenli." What created a sense of community in the area among groups of people from different ethnicities and backgrounds was that they belonged to a lower-income group. In the areas without a development plan, this was reflected as gecekondu and in the areas having a development plan this was reflected as low-quality housing. This structure created a base to support them in the upcoming local elections (Aydın, et al., 2003). Furthermore the ethnic relations and kinship among groups helped Islamic conservative movements to emerge and spread in the district (Kurtoğlu, 2004). The dominant power of the period, $\mathrm{RP}$, successfully used and manipulated the Islamic movements. The domination of the political scene with Islamic ideals fundamentally transformed the way local and central arenas reproduced space (Şahin, 2007).

Melih Gökçek, current mayor of the Metropolitan Municipality of Ankara, served as the district mayor from 1984 to 1989 and started the process. He used policies that would enable the emergence of Islamic enclaves and suburbs where the Islamic lifestyle would be dominant. In this respect, he used planning to legitimate the transformation of public space into mosques, Islamic student hostels, "külliye's," and Islamic housing settlements. A style bearing Seljuk-Ottoman forms and traditional features became the dominant architecture in the district. Through the creation of a new environment by using architecture and planning, they prepared a base for the upcoming elections of 1994 (Şahin, 2007).

With 1994 elections when Turgut Altınok of Milliyetçi Hareket Partisi (MHP) famous for its nationalistic ideology came to the power, transforming the character of the district. The departure from modern Turkish ideology leads to the social reproduction of space resulting in creating a new architectural form and urban forms. Turgut Altınok was chosen to be the mayor of the district in the 1999 and 2004 local elections as well therefore serving until 2009. As he served for 15 years, the transformation process of Keçiören continued without any intervention (Pinarevli, 2005).

One of the most important characteristics of this new local regime was their new approach to alienating the district from the rest of the city while aiming for a new spatial order (Aydin, et al., 2003). The first action that the new municipal government took was to change the emblem of the district into one composed of abstract representations of a crescent and minarets instead of the old one bearing a human figure. Their second action was to change names of the streets. Streets that used to have names related to "peace and freedom" concepts were given the names of martyrs that were killed in southeast Turkey and famous Turkish-Islamic ancestors (Kurtoğlu, 1998). This was how the politicians were using the nationalist and historical values of the residents (Pınarevli, 2005).

The major transformation took place in the public areas used for recreational purposes. The best example of this transformation can be seen in the area containing the municipality complex and its surroundings. Most important of these public areas is the square in front of the Keçiören Municipality building. The arrangements that were done in the area include: the ceremonial area, an open air museum inscriptions of Orhun, statues of famous TurkishIslamic ancestors and Şehitler Anıtı (Martyrs Monument), a waterfall, and a castle together with its fortifications. This area was meant to be a scene where the new ideology could be spatially exhibited from its position on the main artery linking the district to the rest of the city; in other words, this area can be considered as the main entrance to the district. This area where one is obliged to pass in order to enter or leave the district constitutes a border between the Republican Ankara and a newly-emerging Islamic district (Aydın, Bayraktar and Tekkaya, 2003). 
After the transformation of the areas surrounding the municipality complex, the local politicians took the liberty of making further changes. They started to regulate the architecture of the residential areas by bringing standard models for their facades. The façade elements of monumental Seljuk-Ottoman architecture, stylized floral motifs of Islamic art, traditional Turkish carpentry designs, and Sultan signatures were applied to the façades of the residential apartments creating a new eclectic architectural language based on the cultural ideology of Turkism and Islam (Saylan, 2008). Turgut Altınok, former district mayor of Keçiören, on many occasions proudly said that he himself chooses the façade designs of the buildings and sets the use of traditional motifs and certain materials as a rule for the contractors (Şahin, 2007).

\section{The Case}

The Keçiören district was chosen to be the case study of this research for a number of reasons. Firstly, Keçiören is one of the oldest districts in Ankara. That being said, it witnessed many different transformative periods in the history of Ankara. Furthermore, its involvement in the vagaries of history contributes to its significance.

First of all, in the earlier history of Ankara it was used by the upper and middle class as a recreational suburb before and after the establishment of the republic where one could find vineyards and agricultural land. Secondly, during the 1950s Keçiören was one of the places that had received a vast amount of migration which eventually led to the emergence of squatters' camps and caused social and economic degradation in the area. It eventually became a district that could be characterized by its dominant "gecekondu" architecture. Finally, it shines as an important example of the reflection of the political-Islam process. Even before AKP came into the power, under the control of Gökçek, the process of Islamization had started. After 1994, when the moves to isolate Keçiören from the rest of the city started to give results, the process became much more obvious from the social and spatial urban sphere. Today, as it can be considered as the stronghold of the AKP government, the dominant group in the area is composed of supporters of the Party. Bourdieu states that the dominant group has the power to declare their culture as worthy of being sought, which makes Keçiören an example where space is socially reproduced (Bourdieu, 1984).

Another reason why this area was chosen as the case study is that it represents the aesthetic considerations and image of the changing political powers. The series of transformations that took place throughout the political history of the district are spatially reproduced. With the changing political variables and mechanisms of the local municipality in the last two decades, as the local politicians use architecture as a representation of their ideology, the identity of Keçiören continues to change. This spatial representation of the dynamic power and ideology shift makes Keçiören a perfect case. In order to illustrate this transformation that

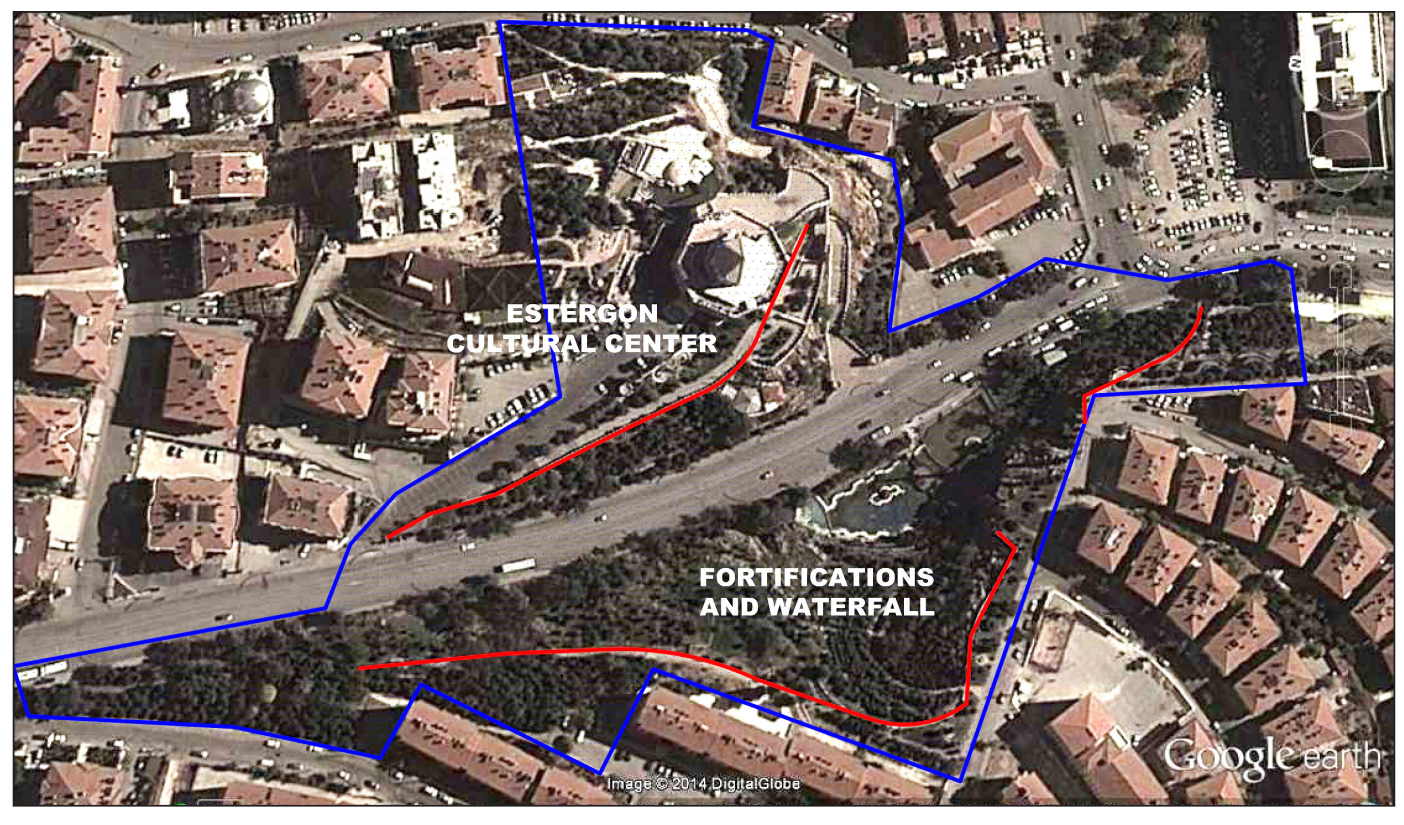

Figure 3. Estergon Castle and its hinterland. Source: Image is taken from Google Earth and the illustration was created by the author. 
uses symbols taken from the collective history, the best example Estergon Turkish Cultural Center will be used.

\section{Estergon Turkish Cultural Center}

Estergon Cultural Center is located along Fatih Boulevard, neighboring the Municipality Complex. Located on the hill behind the municipality building, the Estergon Turkish Cultural Centre provides a vista for visitors. The area where the Cultural Centre is built is designed in terms of landscape accordingly. On the hill that is located against Estergon Cultural Center, the fortifications of the castle are built forming a border for the waterfall (Figure 3).

Starting with the waterfall, it is claimed to be the largest waterfall in Turkey and the largest artificial one in the world. This massive structure extends 180 meters along the Fatih Boulevard. It was designed to be a tourist attraction that would be the symbol of Keçiören (Keçiören'i Adeta Yeniden Yarattık, 2007). The waterfall arrangement includes a composition about the victories of the Turkish nation. Some recreational spaces for the purpose of observatory decks were also constructed on the upper levels of the waterfall structure. (Figure 4).

Estergon Turkish Cultural Center which is as large as an original castle scale-wise, was designed by İbrahim Terzioğlu, assistant president of Keçiören Municipality as a cultural and commercial center. This large scaled project was completed in a period of 6 years' time and opened in 2005.

On the websites of the municipality, it is explained that Estergon Turkish Cultural Centre is constructed to contribute to the urban aesthetic quality of the district. When the Cultural Centre was constructed, the Keçiören community had a new shopping center. The design of the castle was done in light of historical and cultural values by using examples from Seljuk and Ottoman architecture (Estergon Türk Kültür Merkezi, n.d.).

The Cultural Center was named after the original Esztergom Castle in Hungary. The defense of the castle by Ottoman soldiers in the war of 1595 makes this castle famous in history.

The Cultural Center is composed of 3 different parts. The structure of the castle serves as a commercial center on the ground floor, an ethnographical museum on the second level, and restaurant/observation terrace on the last level. On top of the main castle structure the "kümbet" portion is constructed. This Kümbet is used as a place where recreational gatherings are held. The area between the castle and its fortifications extending further up to the hill is designed as Asian gardens. Some restaurants are also present in these gardens constructed in traditional Turkic styles.

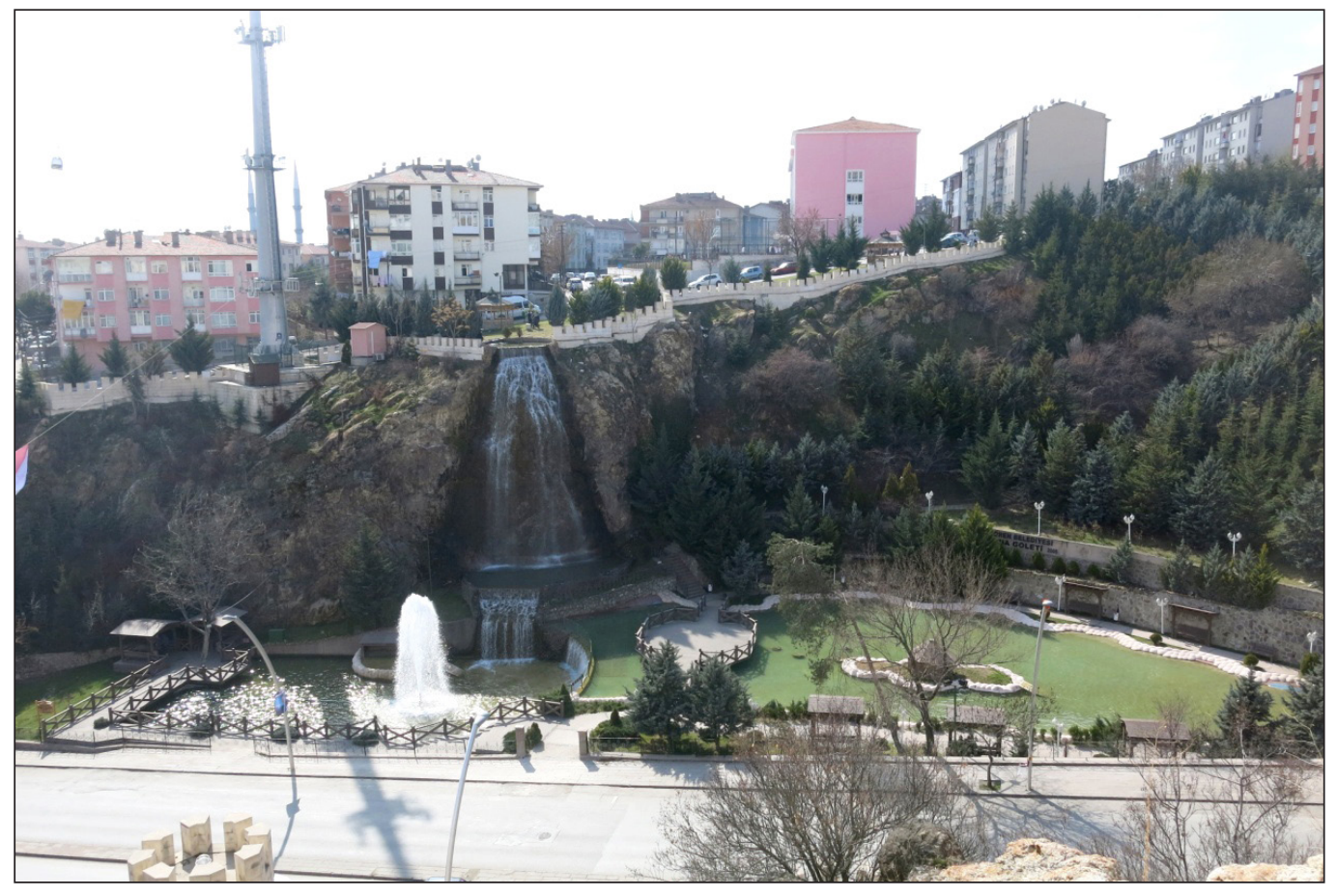

Figure 4. The Waterfall in front of the Estergon Cultural Center.

Source: Photograph by author. 


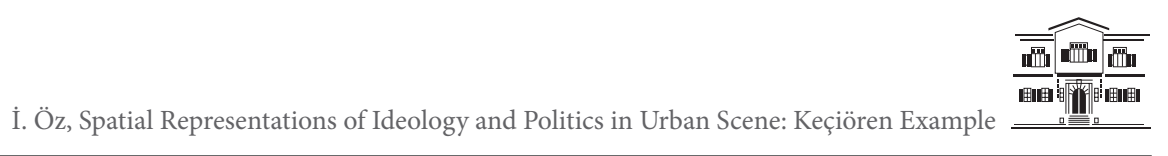

Table I: Estergon Turkish Cultural Center Analysis

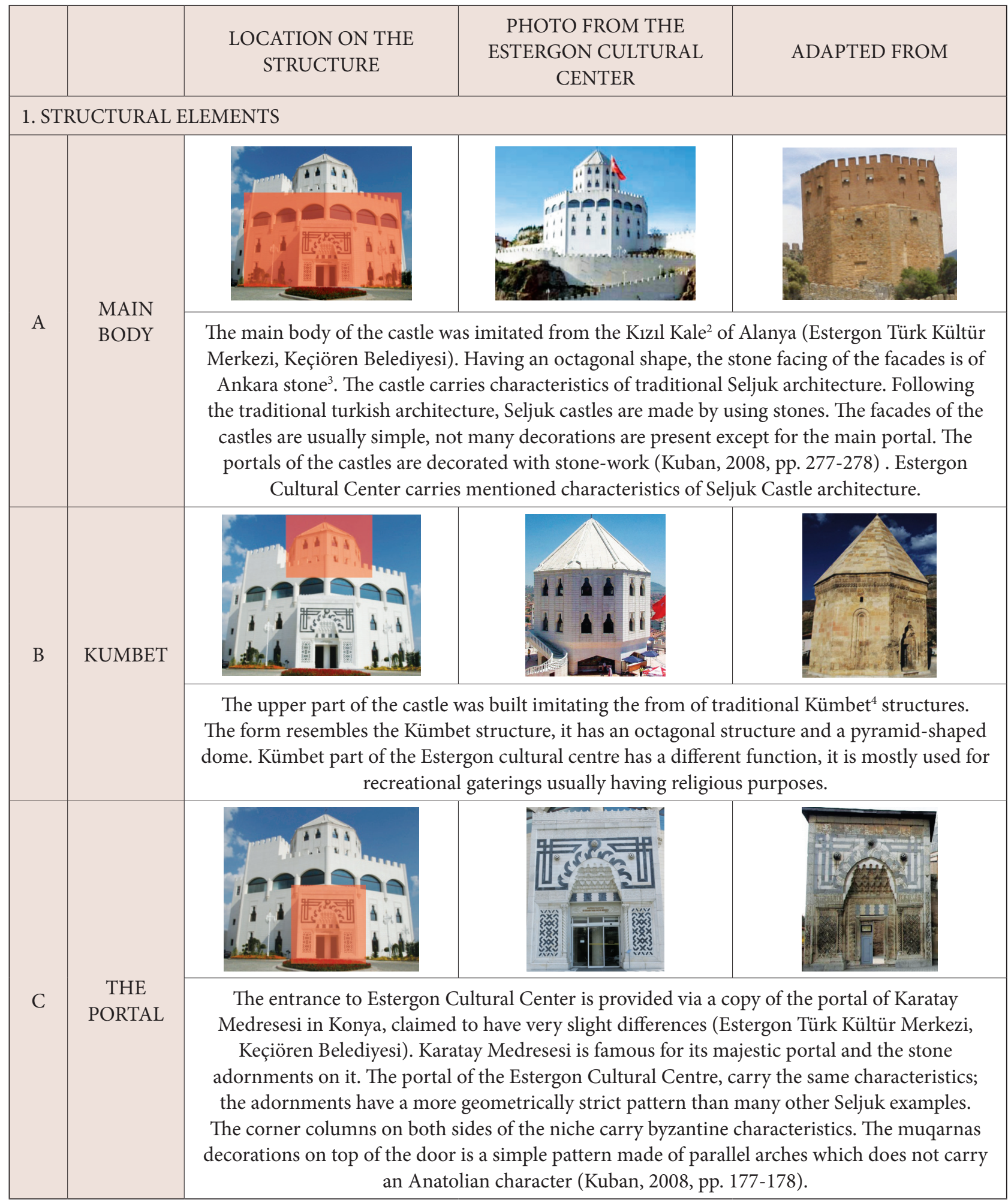


Table I (continued): Estergon Turkish Cultural Center Analysis

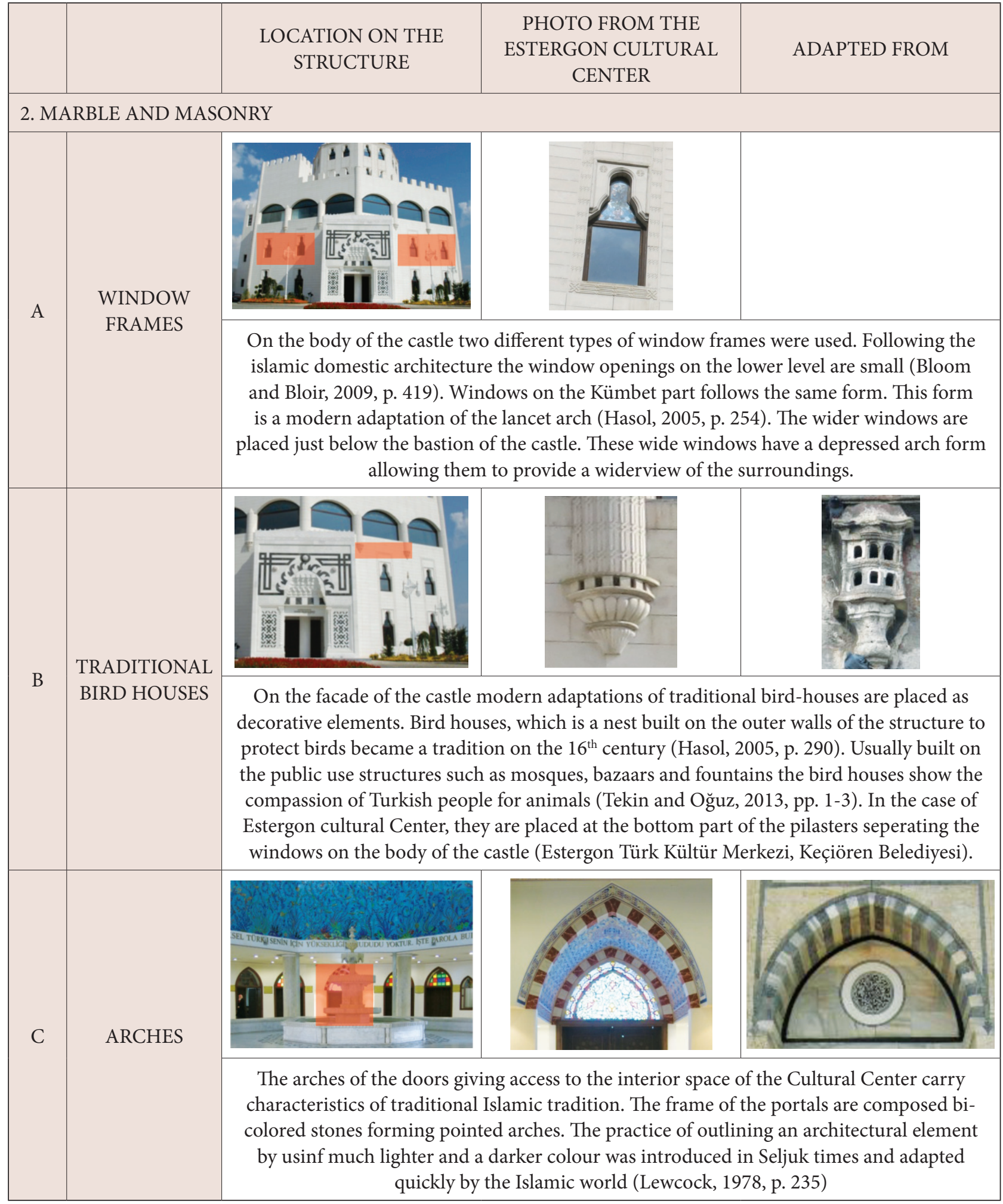


İ. Öz, Spatial Representations of Ideology and Politics in Urban Scene: Keçiören Example

Table I (continued): Estergon Turkish Cultural Center Analysis

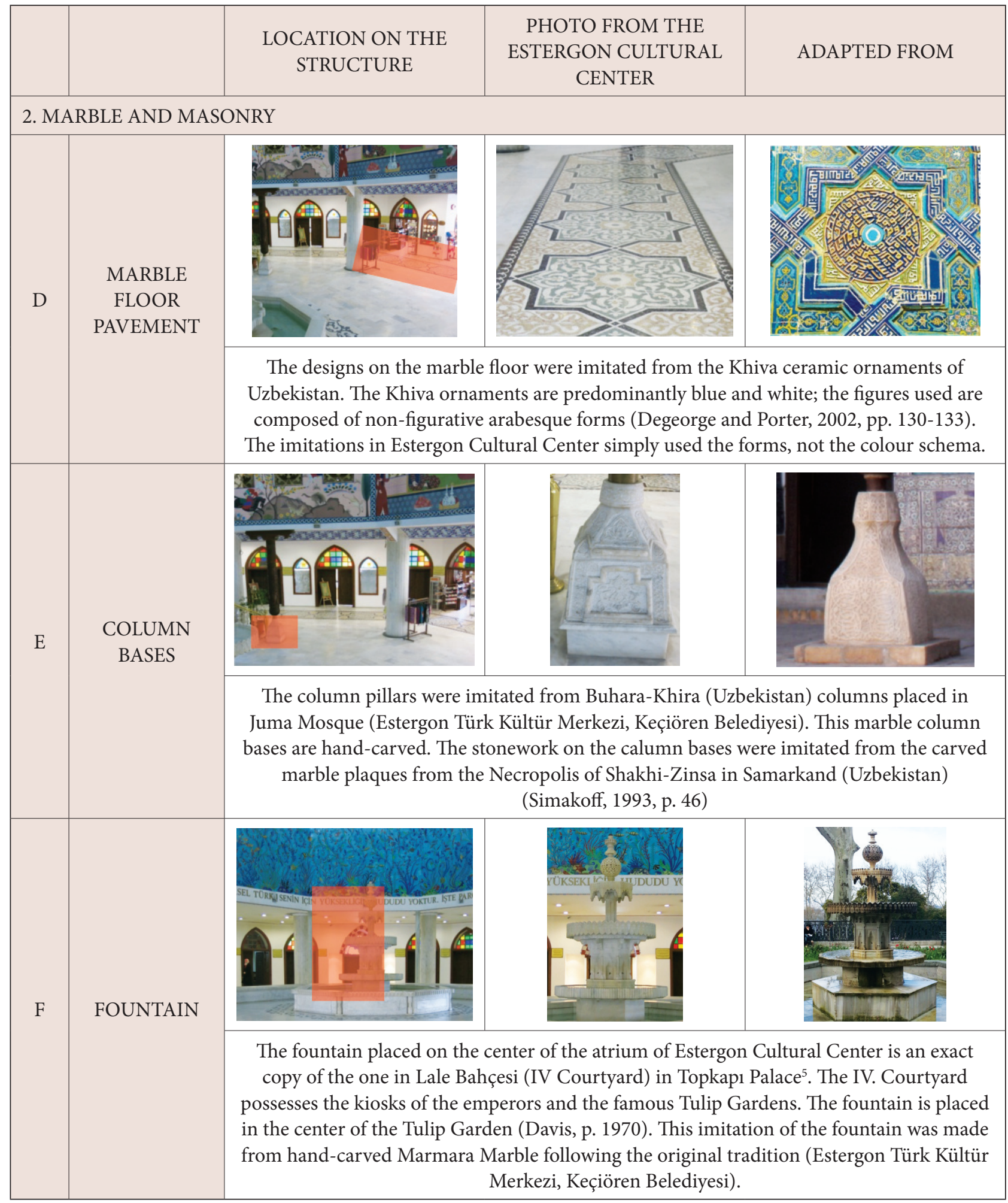


Table I (continued): Estergon Turkish Cultural Center Analysis

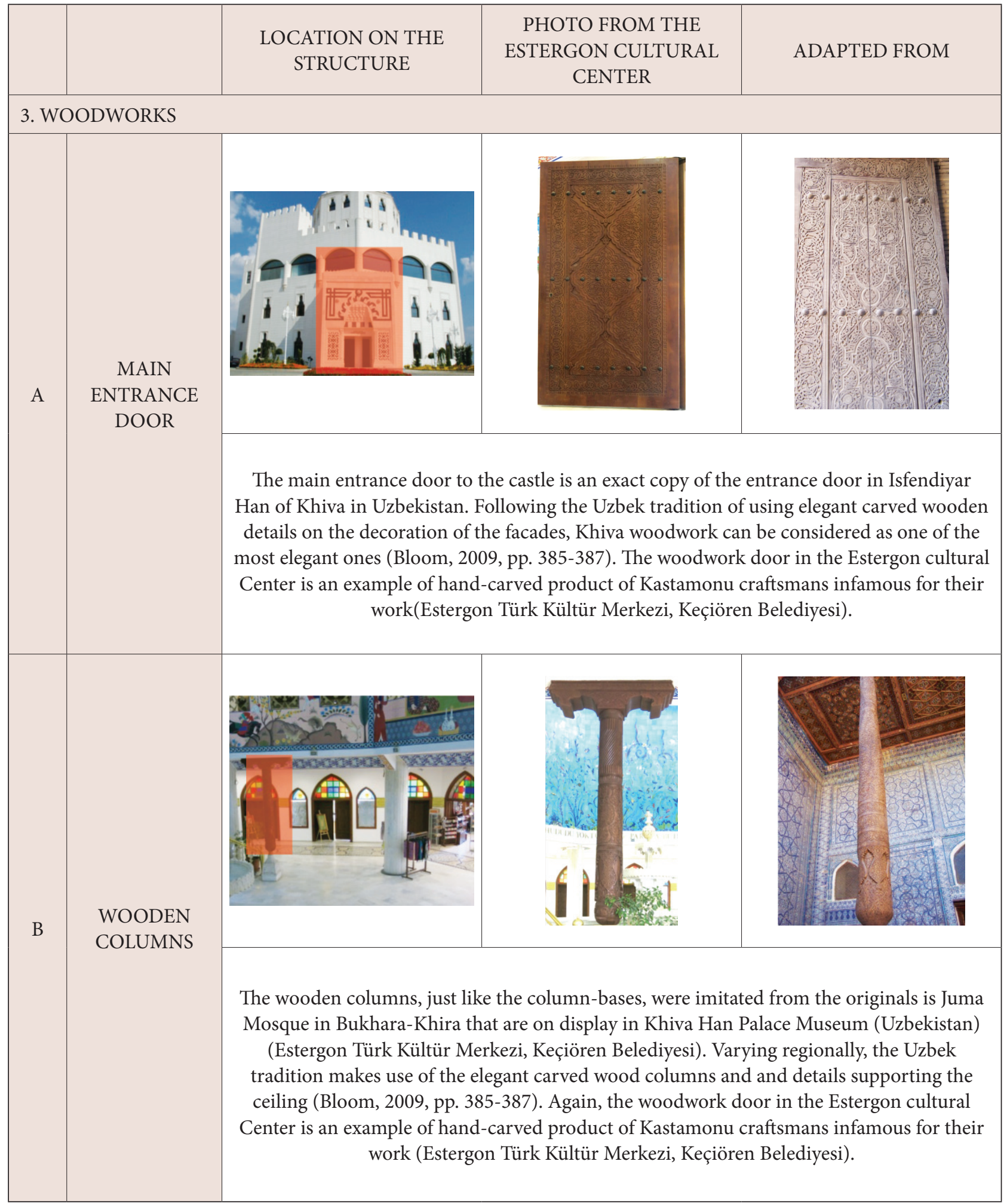


İ. Öz, Spatial Representations of Ideology and Politics in Urban Scene: Keçiören Example

Table I (continued): Estergon Turkish Cultural Center Analysis




Table I (continued): Estergon Turkish Cultural Center Analysis

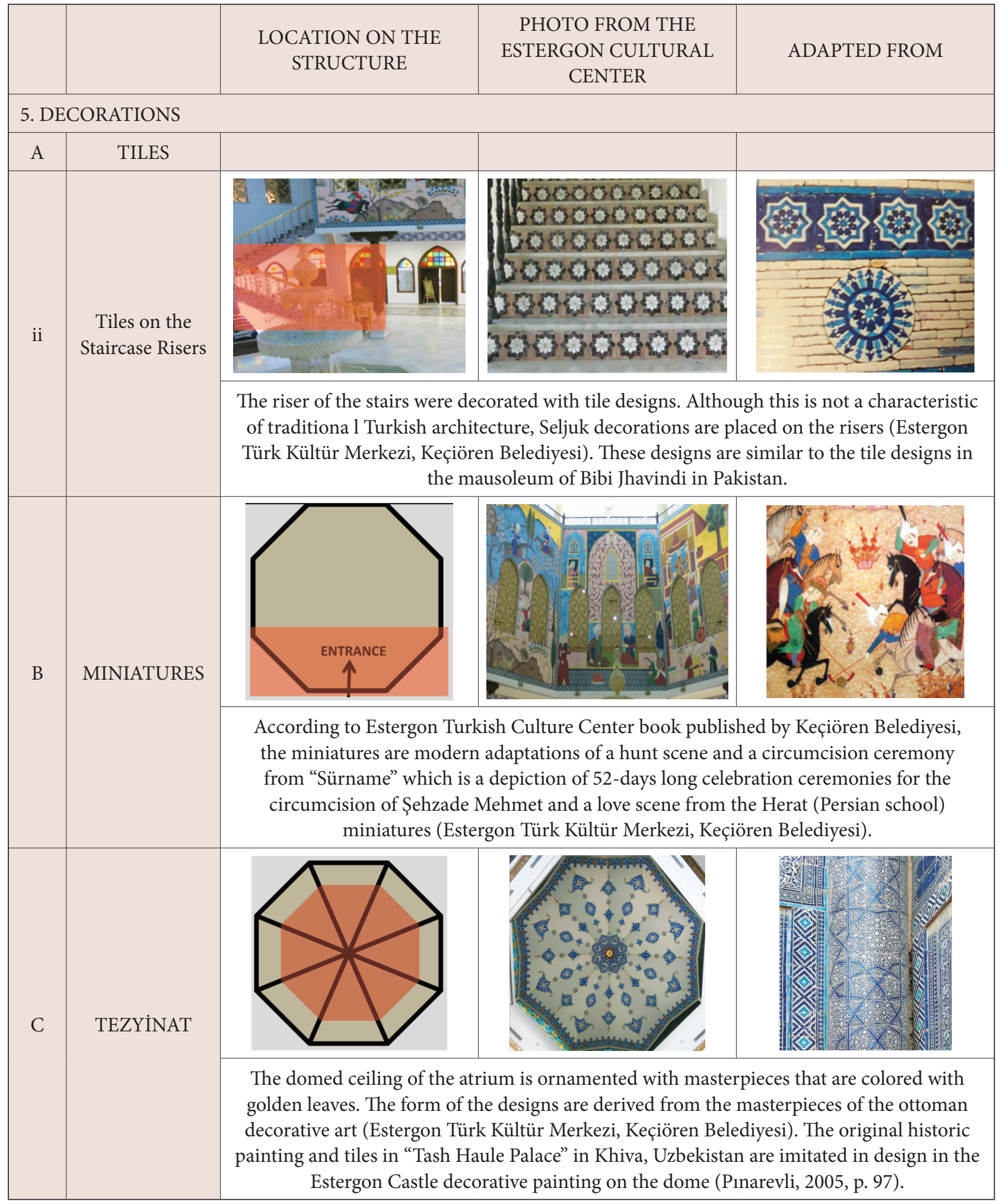


In terms of the decorative elements of Estergon Cultural Center, it is claimed by the municipality that a rich selection of figures from traditional Turkish art was used. The castle was constructed in an eclectic way so that every part of the castle belongs to a famous historical structure or pattern that represents a frozen moment in Turkish Culture.

A comparative analysis of the Estergon Cultural Center with reference to the adapted architectural symbols, images and adornments are given on Table I.

\section{Actors Involved in the Transformation Process}

The domination of gecekondu settlements in the area is very important in terms of understanding the social dynamics of the population. The society can be considered as an important actor during this social and physical transformation of the area. The voter base that enabled local governments with a conservative - Islamist character is responsible for the transformation of the district.

The pass of several gecekondu laws by the Özal government during 1984 and 1985 allowed the construction of buildings up to four-storey high on gecekondu land. This led to the commercialization of the gecekondu and created a new sector. The apartmentalisation of gecekondu can be considered as the way politicians bribe people as once owner built and occupied gecekondu houses were replaced by high-rise apartments, several of them in many cases which are owned by the former gecekondu owner (Erman 2001, p. 987). However, this policy caused the "undeserved earning" concept in a short period of time. A part of the settlement was experiencing further deprivation, while another part was becoming economically better off.

It was after this apartmentalisation process that society realized former rural migrants/gecekondu owners could move to a higher economical class, and more importantly they had the power to shape the city by imposing their way of life and sets of values that were different from those of the urban elites of the period.

Arslan, in his article dated 1989, when the apartmentalisation process was taking place, summarizes that, the local political institutions become more and more important for gecekondu dwellers as their legitimation and the provision of services to the gecekondu relied increasingly on the local government they voted for $(1989$, p. 36). With the results of the 1994 elections, it became clear that the gecekondu population was very effective in the determination of the local election results.
Politicians and local government are also an important actor. When we look at the political history of the district from the last twenty years, we see three political parties that attained power. With the local elections of 1994, Turgut Altınok of MHP was elected to be the mayor of the district while RP was selected for the Metropolitan $\mathrm{Mu}$ nicipality of Ankara. Turgut Altinok continued to be the mayor of the district after the 1999 local elections; however he was representing Fazilet Partisi (FP), the former RP, at this time. Altınok again became the district mayor after the 2004 local elections, this time from AKP. He resigned in order to run as a candidate for the mayor of the Metropolitan Municipality of Ankara, but lost it. After Altınok, the AKP candidate Mustafa Ak came into the power; he still serves as the district mayor. The origin of the transformation in terms of ideology and urban environment can be traced back to this twenty year period.

The concept of modern life and the values and virtues it brought from the perspectives of the middle and upper class was not embraced by the lower class during 1990s. The situation caused the working class to become much more conservative. The political upheavals caused by the economic crisis, terrorist movements in southeast Turkey, coalition governments, and the rise of Islamic power in the political sphere were taken advantage of by the conservative figures like RP and Melih Gökçek on a more local level. The domination of the local arena by Islamic ideals finally changed the way the local and central spheres reproduced and had an effect on the urban planning process (Şahin, 2007, pp. 91 - 93).

MHP, being a nationalistic party, successfully took advantage of the situation, generated nationalist feelings in the Turkish community, and established its election campaign accordingly in the district (P1narevli, 2005, p. 54). As soon as they became the dominant power in the district, they started to transform it spatially according to their ideologies. They not only reflected their ideologies in public images but also they brought regulations to control the aesthetic dimension of the buildings that were going to be built and had already been built.

Even for the construction of the huge complex of Estergon castle, no professional advice or utilization was taken. İbrahim Terzioğlu, claimed that he designed the building himself. In this design process of the Cultural Centre, the third set of actors composed of architects and urban planners were not involved in the design process. The munici- 
pality predetermined all the architectural decisions to be taken, the only thing left for the contractors and architects (as contractors have the authority to produce and design buildings, they can be considered in the same category) was to obey them. Pinarevli summarizes the role of architects in the process by describing them as technicians, not designers (2005).

Although it may seem like an innocent attempt to beautify the city, by limiting an autonomous profession it gave the district a dominant nationalistic and Islamic character and identity which was the main aim of the politicians, projecting their ideologies on space. In order to create Islamic and historical urban values in the district, the local governors neglected contemporary concepts and applications in the fields of architecture and urbanism (Pınarevli, 2005).

\section{Evaluation of Keçiören District Based on the Bourdieusian Framewor}

\section{Transformation before 1980s}

During the first period named as "Urbanization of the $\mathrm{Na}$ tion State" by Şengül, when we look at the stratification of society, we see three different classes: the villagers, the working class, and the middle class. $87.7 \%$ of the population had been living in rural areas having populations below 10,000 and the $16.3 \%$ percent of the total population was settled in urban areas. The period between 1923 and 1937 was the period where a massive migration took place. More than half a million people were relocated to urban areas from rural areas (Aslanoğlu, 2010, pp. 21-23). Of course, compared to modern conditions the number may seem inconspicuous, but at that time serious precautions had to be taken in order to relocate and assimilate the migrated population within the urban areas.

Towards the end of the first portion of this period, just before the economic depression and massive waves of migration from the rural areas, although a stratification of the population was present, there were no serious gaps among different groups that would cause conflicts (Aslanoğlu, 2010, pp. 22-24). The bourgeois class was not yet powerful enough in the cityscape to have control over the judgment of taste in the architectural field. The habitus displayed among the population of the city showed a more or less a homogeneous structure without causing a serious conflict in the different fields.

The emergence of a new architectural style can be considered as an important process in this period, the architec- tural style known as the First National Architectural Style was not caused by social variables. Batur explains this transformation by referring to two facts; the first one being the ideological framework used to create a modern face for the newly founded republic while making use of the traditional elements for the construction of a national identity, and the second one being the improvement of the national economy (Batur 2005). The main aim was to unite the nation under a Turkish identity that contradicted the multicultural social structure of the Ottoman Empire (Şengül, 2001, p. 113).

In this transformative period we witness the emergence of symbols, however this image production did not take place in an organic way. It was attained by making use of the present nationalistic inclinations of people by using a top to bottom approach. The modernization project did not take the local culture as its focus; instead the main aim was to distance modernization from Islamic or Turkish labels as much as possible, thinking that this might ruin the modernization process (Keyder, 1998, p. 29).

The spatial reproduction of politics cannot be described as an organic process that took place as a result of social transformation but it was intended directed effort to restructure a city that would fit into the brand new modern ideological framework. Unknown to the politicians, the economic and political investments realized in the period later contributed to the formation of social class and the creation of greater gaps between these classes. Another point worth mentioning is the insufficiency of the construction program followed. The rate of construction did not answer the demands of the rising population as the rate of migration from rural areas to urban land accelerated towards the end of this period.

Moving to the second contextual phase in the history of Ankara, as mentioned before this period is a very significant one as it is characterized by a wave of migration from rural areas to urban land caused by modernization in the field of agriculture, thereby taking social stratification a step further (Şengül, 2001, p. 123).

Gecekondu settlements that emerged at the fringes of the city and in the urban areas that were intentionally left vacant because they were not suitable for development started to form as a contradiction to the middle class settlements within the urban area. This dual structure of the city started to become a scene of conflict between the gecekondu dwellers and the state (as they simply occupied 
the land) and middle class as the gecekondu dwellers keep sustaining their rural lifestyle which threatened the middle class style lifestyle within the city (Şengül, 2001, p. 124).

The middle class that created hegemony within the urban land started to lose its power and started to be replaced by a new layer of citizens. However, the layer that the middle class occupied in the previous period never disappeared from the urban scene; they became less powerful but remained as the main economic actors. On the other hand, the migrated population forming the gecekondu, lowincome informal settlements, obstructed the political and cultural project of the middle class (Şengül, 2001, p. 125).

The values that were brought by the migrants to the urban areas were preserved in a conservative way. The political inclination of this class was towards supporting the conservative parties.

The lack of basic urban services and the exclusion that gecekondu dwellers faced when they moved to the bigger cities from rural lands caused the radicalization of the gecekondu class. The people that moved from rural to urban lands unconsciously created a homogeneous class or group. This phenomenon was accomplished by relations of "hemşehrilik" and family. In the process of settling into the urban scene, the choice of location and this family and hemşehri network played a key role. As a result the gecekondu neighborhoods were segregated within themselves in terms of ethnicity and hometown (Şengül, 2001, p. 127). The fact that they were sharing the same space and that they were outcasts excluded by the middle class brought them together (Erman, 2004).

These significant neighborhood relationships became indispensable dispositions that could not be sacrificed easily as they created a "sense of one's place" through networks that emerged in the area.

Although in the first decade of this period the first reactions and the policies followed were towards the demolition of these settlements, the 1960s showed a different character. Some strict demolition and prohibitions took place but a better more positive approach was taken towards this lowincome population. This was not an innocent act though. This shift in attitude was rooted in political concerns. With the effect of the migration movements, the balance that had been established in terms of politics started to shift. The competitive environment that was caused by the shift towards a multi-party political life made the increasingly numerous low-income population an indispensable element of the society (Şengül, 2001, pp. 128-129).

One point worth mentioning about the previous period; the bureaucrats that played any role in the establishment of the republic spent an immense effort to impose what they consider to be a contemporary and modern life-style. They wanted to set an example to others by being the first ones to live in that particular way. Their aim was for people to forget the past and internalize modern culture. This attitude brought its opposite after some time had passed (Dener, 1996, pp. 101-102). Bourdieu names this process as symbolic violence. Symbolic violence is the imposition of a set of systems, values, and symbolisms upon groups or classes in such a way that they are experienced as legitimate (Jenkins, 1992, p. 104).

The conservative part of the population that valued its original culture started to react to the modern part of the society as they desired to live how they wanted. The lower-income class that did not possess significant economic capital found ways to express themselves. They started to create values that would be coherent with modern western culture and revolt against it at the same time. They created their own subculture; they had their own music, clothing, entertainment, and housing styles. The popular culture "arabesk" became successful against its struggle with the elite culture that had been imposed on society and became visible in the urban scene (Dener, 1996, pp. 101-102).

When we look at this transformation from a Bourdieusian perspective, we see that changing life styles brought a change in habitus for the gecekondu dwellers. Once when they were living in the rural areas, each village or each agglomeration had their own dispositions and values which in turn would create the specific habitus for the people living there. Having moved to the city - although as emphasized before, the migrants move to those places where their relatives or 'hemşehri's live - in looking to live in a group with similar habitus, urban life triggered the transformation of habitus as well. This population living in the urban land was pressured to be modern but could not abandon the values and disposition they had carried over from their previous rural way of life. Although the system treated everybody as equals when in fact they were actually competitors that started the competition with different handicaps based on cultural background (Jenkins, 1992, p. 111).

As for the Keçiören case, emphasized in the case study chapter, the area had been left to its own devices up un- 
til the 1980s, after the situation took an irreversible turn. The former low-income class actually constitutes the core of the people living in the Keçiören area today. Therefore the previous transformation that they had been through should be emphasized.

\section{Transformation after 1980s}

At the beginning of 1980s, the population was mostly constituted of people that did not experience the establishment of the republic first-hand. Therefore, as time passed the population became skeptical towards promises of a "bright and prosperous future." This showed itself as a process of questioning identity, belief and value at the social level. This tendency was first present in the part of society which had been most recently urbanized, but then this skepticism sprawled to other sections of the population and started to affect ideas about the contemporary life-style of society. This questioning finally reached a point where the Kemalist modernization program began to be doubted. The criticisms rose above the issues of secularism and the nationalist history of Turkish Republic. The anti-Kemalist groups and Islamist groups took advantage of this unstable political situation and started to gain more and more power in the political arena while conflicts seemed to rise in every level (secularism vs Islam, Turks vs. Kurds, rationalism vs. religion, urban vs. rural, old vs. new) within the urban community (Kasaba, 1998, p. 2).

To look at the implications of the military coup d'état issue in more detail, at the beginning of the 1980s during the process of transformation from labor-based urbanization to a capital-based one, the military played a key role (Güler, 1992). The military regime not only put an end to the growing public struggle within the community but it also ended the leftist movement and in this way created the basis for the emergence of urban entrepreneurship that would organize the urban sphere according to the needs and requests of capital. (Şengül, 2001, pp. 139-140).

The process of urbanization of capital changed the class structure and its spatial reflections. Different classes became more and more distant, causing social stratification to be experienced at its greatest. For the middle-class the class structure became more and more complex in the urban sphere (Şengül, 2001, pp. 142-143). As Bourdieu argues, class distinctions in the economic sphere generate symbolic distinctions in terms of culture which in turn regenerate and legitimate the class structure (Gartman, 1991, p. 421)
This further stratification was actually caused by the earlier strategies implemented by the politicians. The reformists of the early years of the republic over-applied their strategies of modernization and tried to change the lifestyles, actions, and daily habits of the people which in the following years became visible as a conflict between the modernists and the Islamists within the population. As Kemalists ruling the state internalized an approach which put westernization and modernization as the ultimate form of modernization, they viewed societal differences (ethnical, ideological, religious or economic) as elements that threaten progress, not as components of a pluralistic democratic society (Göle, 1998, p. 73). People belonging to different groups, having different sets of values, and having different habitus were not acknowledged at first, and then were excluded, and in the end strict policies were implemented against this group.

To conclude, what happened up until the mid-1980s, by using Bourdieu's concepts, we see that the habitus of gecekondu dwellers had transformed. As it was mentioned before, culture and habitus are not static 'things,' they are in fact dynamic processes that evolve with the transformations taking place in different fields. Stratification in the economic field conditions different class habitus, which in turn is the reason different cultural tastes are generated (Bourdieu, 1984, pp. 169-175).

In the mid 1980s, with the rise of the Islamic movements, a historical turnaround was experienced (Göle, 1998, p. 73). The exclusion strategies were not successful anymore; therefore in the political field some new strategies were produced to make this group a part of the urban sphere. It became necessary to understand the how the nature of conflict and tension represented itself at the emotional, personal and symbolic level (as cited in Göle, 1998, p. 73).

$\mathrm{RP}$, the Islamist party, set its ideology towards a framework that would address the members (identity and to be recognized within the urban arena) of the lower-class that would lead the way to becoming the dominant political power (Göle, 1998, p. 81). With the new-rightist ideology, the implementation of strategies towards the gecekondu population of the city had started (Şengül, 2001, pp. 142-143).

In 1994 the local elections resulted in the victory of RP. This Islamist party came into power in the two largest metropolises: Istanbul and Ankara. This came as a shock to the secularist segments of the population and power holders, however, the anti-globalization, anti-western dis- 
course of the Islamic Party attracted the marginalized city population who became more and more segregated in the urban space by the policies of globalism (Keyder, 2005; Tuğal, 2002).

The compromises (gecekondu amnesty law) given to gecekondu owners were not the only factor that decided their political behaviors, ethnic and religious factors as well as the economic policies were effective elements of the behavior mechanism. Urban poor, however heterogeneous they can be within their own community had the potential to be united under a political project. However, this potential can only be activated through the existence of a political organization which can create a realistic alternative project. In response to the further segregated character of the cultural and political fields, a political approach putting the concept of identity at its core was adopted which was thought to answer the need to gather different groups together on a shared political arena (Şengül, 2001, pp. 144-147).

After the fall of RP due to the increasing tension between the RP and secularist state institutions, the AKP following its footsteps, was established and took over control of the metropolitan municipality of Ankara. AKP appeared to be successful in gathering the urban poor under a single ideology. Although the AKP government caused urban poverty to sprawl to a larger section of society, the lack of a realistic alternative from the political left enabled AKP government to do so (Şengül, 2001, p. 148). The ideology they created presented itself as a convincing "alternative modernity" that does not deny its Islamic roots (Keyman and Koyuncu, 2005).

The Islamist politicians took advantage of the further segregated urban field and gave compromises, mainly economic ones, to the excluded population. This caused a shift in the amount of capital the lower-class was in possession of. As their economic capital increased, as well as symbolic capital (therefore social) provided to them via their patronage relationship with the politicians, this class started to gain more power and became more effective within the urban sphere. The symbolic violence practiced by the culturally and economically privileged class lost its intensity. Even in the last decade, this symbolic violence has been turned around, with increasing social capital in the possession of the former lower-class, today's middle class.

Within the cultural field, this political shift led to the change of the dominant culture. For the perception of aes- thetics or the judgment of taste the dominant view was still in the hands of the culturally-privileged class, mostly the descendants of the urban elites from the last period. However, the changing political structure brought a shift in the dominant class within the city towards the voter base for the dominant political party.

The domination of the cultural field is acquired by the possession of the cultural capital. As it is stated in the theoretical framework chapter, cultural capital is acquired via education. Although the modern education system seems like a mechanism that assumes everybody as equals, this situation creates a biased context. The children coming from families that are in the possession of cultural capital are most favored in the cultural field as they possess a greater amount of cultural capital by default. Therefore, the new politically dominant class, former gecekondu population does not have the power to dominate the cultural field and set standards for the perception of aesthetics. Although they do not possess the power to change the perceptions of aesthetics, with the symbolic power and the actual power they possess via politicians, they have become the dominant class to practice the dominant culture. This opposition is classified by Wacquant (2011, pp. 102-103) as being the opposition between those who are in the possession of economic capital but have few cultural assets (dominant class in the urban sphere) and those whose assets are mostly composed of cultural capital (dominant class in the cultural field).

In spite of the fact that there is an endless conflict between two contradicting cultures, the aesthetic perception of the former gecekondu population is not actually very different from the so-called high culture. Called as petite bourgeoisie by Bourdieu, the middle class (former working class) aspires to attain the distinction of the bourgeoisie (urban elites), however, it does not possess the required capital in the cultural field or habitus to achieve it. Therefore, the middle class in turn adopts a life-style that is not their own by superficially borrowing from the legitimate culture, transforming into something they are not (as cited in Garrick, 1997, pp. 424-426).

However, the point worth mentioning is that Bourdieu defines aesthetic judgment as an eminent social faculty resulting from social stratification and education. To appreciate a kind of work of art, one needs necessary type and amount of cultural capital. Furthermore, taste and aesthetic judgment of a class represent themselves through 
the distance of classes: "taste is first and foremost distaste of the taste of the others" (Bourdieu, 1984, p. 56). This is because any type of cultural practice takes its social meaning and its ability to signify social difference and distance not from some intrinsic property it has but from its location in a system of likes and practices (Wacquant, 2011, p. 103). Relating this to the case study of this research, the established cultural norms that put western art/architecture as the products that signify modernization or aesthetics after the establishment of the republic exclude any object that has ethnic or historical (orientalist) value. Therefore, consciously and unconsciously modern products of architecture mimicking Western traditions become the beautiful while the ones representing an orientalist style are labeled as kitsch.

Of course this situation is reflected as a conflict in the urban scene. "Taste represents the concealed exercise of power; it is a matter of course, the natural difference that has grown apart from the social" (Rahkonen, 2011, p. 126). Throughout the city it is possible to see the spatial appearance of ideology. Although the overall appearance of the cities seemed secularized, it became more and more Islamic with the integration of the Islamic life-style to the existing urban pattern (Tuğal, 2009, p. 55). In the name of gecekondu transformation, many wide-scale urban projects were implemented (Tatar, 2012, p. 37). Another policy that the government adopted was to 'rehabilitate' and 'preserve' cultural heritage, which in turn was the destruction and re-creation of a nostalgic model of the city (Sulukule urban-renewal project and the upcoming case of Ankara Castle and surroundings). Gülhan concludes that these spatial transformations usually resulted in class-based spatial re-arrangement as the rehabilitated neighborhoods are not given back to the lower-classes who inhabited the area, but rather are settled by people of the middle and upper classes (2011).

On a smaller scale, the example of Keçiören was chosen to represent this distinction at its best. Keçiören, being a former gecekondu settlement and being infamous as a stronghold for the AKP, represents this distinction in its physical environment. The emergence of the eclectic architectural style presented in the before was accomplished as a result of this political and social process.

In the context of symbolic capital, objects can be described as the abstract reflections of their environment and can have symbolic capital values. Representing the environment's cultural value by being the symbolic representations of them, this symbolic $\mathrm{c}$ apital can be found embed- ded in the physical space. A cultural commodity becomes significant and implies a symbolic power not because of its material existence but from its social significance (Susen, 2011, p. 180). Urban landmarks become significant in an environment as they carry a symbolic value representing cultural, and in the Keçiören example, political stances that provide a certain prestige to their environment. The Keçiören area, possessing various landmarks (Estergon Cultural Center, the fountains, as such) is an example case study where a culture is imposed as a result of the changing political field. Although the construction of Estergon Castle, the renewed municipality building and many other attempts to change the face of the district may seem like actions that have been taken to beautify the city, the symbolism they possess cannot be denied. The detailed analysis of the symbols that the Estergon Cultural Center has was given in the previous section of this article. From that section, the use of the symbols and creation of symbolic capital can be seen. The symbols that were used on the structure actually reflects the attempts to form a bond between the contemporary culture and the segregated population. The use of such symbols started to become the signature of the ideology and the population that supports the politicians.

From a different point of view, the city became segregated in the social sphere as well. As an attempt to distance themselves from the cultural norms of the former gecekondu residents, the former urban-elite population became more self-enclosed and reactive against the others. The conflict became visible in every field - political, social, cultural and economic. As the dominant class strove to distance themselves from individuals that represent other taste categories, this segregation at the spatial and social level became meaningful. When the popular taste embraces what is considered to be the 'good taste', the pure taste becomes vulgar (Rahkonen, 2011, p. 127) which leads to an endless conflict in the cultural field.

To conclude, the transformation that has been taking place in Keçiören since 1994 has been taking place in many different social scenes. Described as fields by Bourdieu, the struggle to gain profit on the urban land can be explained as the interaction between different fields (political, cultural and economic) on a broader scale. The culture and its reflections on space and society in Keçiören is both the result of these relationships between different fields and the tendencies of the residents that is rooted from their habitus. 


\section{Conclusion}

The aim of this study has been to make an analysis of the transformations that have been taking place in Keçiören district of Ankara since 1994, not only in the architectural or urban fields, but also in the political, social, economic, and cultural fields. To that end, the primary element of analysis in this study has begun the emergence of a new architectural style during the 30 year period since 1994 that imitates the past with a modern approach, not only in terms of urban and architectural quality but also from social and political perspectives that are embedded in the "culture," resulting in a total transformation of Republican Ankara..

The ideological transformation process that started in Keçiören in 1994 and its effects on different spheres makes this a unique case. Formerly a gecekondu settlement that was despised, and today being one of the most favorable districts in Ankara with a population mostly composed of AKP supporters, Keçiören can be classified as the spatial representative of shifts in the political sphere. However, concluding that these changes in different spheres are the mere result of political shifts is insufficient. Therefore by using Pierre Bourdieu's sociological notions as elements of interpretation, I have aimed to explain the social and cultural motivations, values, and dispositions of people that are acquired unconsciously and that shape the cultural field and its reproduction in terms of space. Political domination can be considered a result of agent based behaviors while the actions of politicians result in spatial and cultural changes that affect an agent's life. It may be suggested that dominant powers and agents or groups reproduce each other. As in the example of Keçiören, the former gecekondu inhabitants formed the core voter group for Nationalist/Islamic elements to come into power. Political parties, by using people's different needs, especially the need to attach themselves to a certain identity, reproduced an urban environment that would change the agent's lifestyle.

This transformation taking place with the rise of the AKP is not limited to Keçiören. Although their most extensive transformation projects were implemented in Ankara and Istanbul, in almost every city and town, the rise of the new eclectic architecture that was described in this study may be observed. What makes Keçiören more striking in this sense is the symbolic meaning it was attained. Some points that contribute to the symbolic importance of the area can be exemplified as: the prime minister of Turkey, Recep Tayyip Erdoğan keeping residence in Keçiören and
Melih Gökçek's (the mayor of Metropolitan municipality of Ankara) time as mayor of Metropolitan Municipality of Ankara. These attributes contribute to the idea of Keçiören being "the base of the AKP government".

The emergence of this eclectic architectural style is still an ongoing process. For the Keçiören district, many projects following this path have either commenced or are about to be started. However, as mentioned above, this is not limited to Keçiören; the use of traditional Ottoman/ Seljuk elements can be seen throughout the city. The new clock-towers (52 of them) are distributed among the main squares in the city, the arches that were placed on 5 different entrances to the city of Ankara, or the redesigning of the Gazi University façade are examples that maybe seen at the first glance. What is criticized about these cases is the false consciousness that was created on purpose. Although these may seem like innocent efforts towards the beautification of the urban environment, the identity politics of the dominant political power, by using the architectural and urban elements without any professional assistance, leads to the intentional Islamisization of the district(s), not only in terms of physicality but also in terms of social and cultural contexts.

\section{Notes}

1 For the implementation of an economically and socially based urban transformation project at the Northern Entrance of Ankara, a new law was passed through the parliament; the North Ankara Transformation Project Law No: 5104. As the necessary legal background was provided a massive transformation project began to be implemented (Tuçaltan, 2008). This project did not remain as the sole example.

2 Kizllkule is an octagonal-shaped castle made out of red bricks which is the reason it was given the name Red Tower. It is situated in the Alanya Harbor. It is a work of Seljuk's and was built in 1222 by Ebu Ali rehç el Kettani ("Alanya Kalesi” n.d.).

3 Ankara Stone (as it is densely found in Ankara-Gölbaşı region), also known as andesite is formed due to volcanic activities. Andesite usually has a light pink-grey color

4 Hasol (2005, p. 293) explains Kümbet as being sepulchers in Seljuk architecture resembling the traditional tomb-towers of the Turks. They were built as stone structures having a pyramid-shaped dome. Tuncer (1986, p. 12) further explains that Kümbet architecture were under high influence of Persian and Sassanid architecture during Seljuk period. Kümbets had octagonal plans, conical hats and they started to be widely used times of Anatolian Seljuks.

5 Topkapı Palace is the imperial palace of the Ottoman Empire. It was started to be built in 1460 and completed in 1478, 
covering an area of $700.000 \mathrm{~m} 2$. It was used by 31 different emperors throughout 400 years (Davis, 1970).

6 A romantic art movement that influenced Europe between 1890-1910. This style aims to create an original form, not adapting old traditional styles (Hasol, 2005, pp. 50-51).

7 A motif claimed to be derived from a lotus leaf by some or derived from a bean life by others, literally means curves. They are an essential element of illumination in the designs (Birol and Derman, 1991).

\section{References}

Akın, E. (2007). Kentsel gelişme ve kentsel rantlar: Ankara örneği. Unpublished doctoral dissertation, Ankara University Social Sciences Institution, Department of Political Science and Public Administration, Ankara.

Alanya Kalesi. (n.d.). Antalya il Kültür ve Turizm Müdürlüğü. Retrieved March 20, 2014, from http://www. antalyakulturturizm.gov.tr/TR,67819/alanya-kalesi.htm

Allen, D. E. and Anderson, P. F. (1994). Consumption and social stratification: Bourdieu's distinction. Advances in Consumer Research, 21, 70-74

Ankara University Social Sciences Institution, Department of Political Science and Public Administration, Ankara.

Arslan, R. (1989). Gecekondulaşmanın evrimi. Mimarlık, 27(238), 34-37.

Aslanoğlu, İ. (2010). Erken Cumhuriyet Dönemi mimarliğı. İstanbul: Bilge Kültür Sanat.

Ataöv, A. and Osmay, S. (2007). Türkiye'de kentsel dönüşüme yöntemsel bir yaklaşım. METU JFA, 24(2), 57-82.

Aydın, Ö., Bayraktar, N. and Tekkaya, E. (2003). Cumhuriyet ilçesinde aykırı bir ilçe: Keçiören. Mimarlık, 307, 56-59.

Baştuğ, S. (1979). Urban growth and cultural change: two squatter settlements in Ankara. Unpublished doctoral dissertation, Middle East Technical University, Ankara.

Batur, A. (2005). A concise history: Architecture in Turkey during the $20^{\text {th }}$ century. Ankara: Chamber of Architects of Turkey.

Birol, İ. and Derman, Ç. (1991). Motifes in Turkish decorative arts. İstanbul: Kubbealtı Akademisi Kültür ve San'at Vakfı.

Bloom, J. and Blair, S. S. (2009). The grove encyclopedia of Islamic art and architure (Vol. 3). New York: Oxford University Press.

Blunden, A. (2004). Bourdieu on status, class and culture. Retrieved 20.03.2014, from http://home.pacific.net.au/ andy/works/

Bourdieu, P. (1977). Outline of a theory of practice. Cambridge: Cambridge University Press.

Bourdieu, P. (1984). Distinction. Cambridge Harvard University Press.

Bourdieu, P. (1986). The forms of capital. In A. H. Halsey (Ed.), Education: Culture, economy, and society (pp. 46-58). New York: Oxford University Press.
Bourdieu, P. (1989). Social space and symbolic power. Sociological Theory, 7(1), 14-25.

Bourdieu, P. (1990). The logic of practice (R. Nice, Trans.). Cambridge: Polity Press.

Bourdieu, P. (1992). On symbolic power. In J. B. Thompson (Ed.), Language and symbolic power (pp. 163-170). Cambridge: Polity Press.

Bourdieu, P. (1996). Vilhelm Aubert memorial lecture: Physical space, social space and habitus. Paper presented at the Oslo, Department of Sociology, University of Oslo and Institute for Social Research.

Bourdieu, P. (1998). Practical reason: On the theory of action. Stanford University Press.

Bourdieu, P. (1999). The weight of the world: Social suffering in contemporary society: social suffering and impoverishment in contemporary society. Cambridge: Polity Press.

Bourdieu, P. and Wacquant, L. (1992). An Invitation to Reflexive Sociology. Cambridge: Polity Press.

Çalışkan, O. (2009). Forming a capital: Changing perspectives on the planning of Ankara (1924-2007) and lessons for a new master-planning approach to developing cities. Metropolitan Form, Autumn 2009, 23-53.

Davis, F. (1970). The Palace of Topkape in Istanbul. New York: Charles Scribner's Sons.

Degeorge, G. and Porter, Y. (2002). Iran and Central Asia, fourteenth to nineteenth century the art of the Islamic tile. Italy: Flammarion.

Dener, A. (1996). Hangi ideoloji, kimin erki, ya acılı arabesk? In Sempozyum: İdeoloji, Erk ve Mimarlik (pp. 4-9). İzmir: Çimentaş.

Deriu, D. (2013). Picturing modern Ankara: New Turkey in Western imagination. The Journal of Architecture, 18(4), 497-527.

Elçin, T. (2008). Bürokrasinin mimari görünümü. Unpublished manuscript. Ankara Üniversitesi Siyasal Bilgiler Fakültesi Siyaset Bilimi Ve Kamu Yönetimi Bölümü, Ankara.

Eldem, S. H. and Akozan, F. (1982). Topkapı Sarayı. İstanbul: Kültür ve Turizm Bakanlığı Eski Eserler ve Müze Genel Müdürlüğü.

Erman, T. (2001). Representations of Rural Migrants in the Academic Discourse the Politics of Squatter (Gecekondu) Studies in Turkey: The Changing Representations of Rural Migrants in the Academic Discourse. Urban Studies, 38, 9831002.

Erman, T. (2004). Gecekondu çalışmalarında 'öteki' olarak gecekondulu kurguları. European Journal of Turkish Studies, 1. Retrieved March 20, 2014, from http://ejts.revues.org/85

Estergon Türk Kültür Merkezi. (n.d.). Retrieved 20.03.2014, from www.kecioren.bel.tr/ESTERGON_TURK_KULTUR_ MERKEZI-5-sosyal-tesis.html 
Garrick, B. (1997). Producing and practising social justice policy in education: A policy trajectory study from Queensland, Australia. International Studies in Sociology of Education, 7(2), 157-179.

Gartman, D. (1991). Culture as class symbolization or mass reification? A critique of Bourdieu's Distinction. American Journal of Sociology, 97(2), 421-447.

Göle, N. (1998). Modernleşme bağlamında İslami kimlik arayışı. In S. Bozdoğan and R. Kasaba (Eds.), Türkiye'de modernleşme ve ulusal kimlik (pp.70-81). İstanbul: Tarih Vakfi Yurt Yayınları.

Gülhan, S. T. (2011). Devlet müteahhitlerinden gayrimenkul geliştiriciliğine, Türkiye'de kentsel rant ve bir meta olarak konut üreticiliği-Konuta hücum. Birikim, 270, 27-33.

Günay, B. (2006). Ankara çekirdek alanının oluşumu ve 1990 Nazım Planı hakkında bir değerlendirme. In T. Şenyapılı (Ed.), Cumhuriyet'in Ankara'si: Doç. Dr. Özcan Altaban'a armağan (pp. 61-118). Ankara: ODTÜ Geliştirme Vakfi.

Hasol, D. (2005). Ansiklopedik mimarlık sözlüğü (9. ed.). İstanbul: Yapı-Endüstri merkezi Yayınları.

Hillier, J. and Rooksby, E. (2005). Habitus: A sense of place. Hants: Ashgate.

Jenkins, R. (1992). Pierre Bourdieu. London: Routledge.

Jenkins, R. (2002). Pierre Bourdieu: Revised Edition. London: Routledge.

Joas, H., and Knöbl, W. (2011). Between structuralism and theory of practive: The cultural sociology of Pierre Bourdieu. In S. Susen and B. S. Turner (Eds.), The legacy of Pierre Bourdieu (pp. 1-32). London: Anthem Press.

Kalaycıŏlu, M. (2006). Poverty mapping with geographic information systems: A case study in Keçiören district, Ankara. Unpublished Master's Thesis. Middle East Technical University The Graduate School of Natural And Applied Sciences, Ankara.

Kartal, K. (1982). Ankara as the focus of social change in the process of urbanization, In The Urban Integration (pp. 123-163). Ankara: The Turkish Society for Social Science Publications.

Kasaba, R. (1998). Eski ile yeni arasında Kemalizm ve Modernizm. In S. Bozdoğan and R. Kasaba (Eds.), Türkiye'de modernleşme ve ulusal kimlik (pp. 12-28). İstanbul: Tarih Vakfı Yurt Yayınları.

Kaya, T. (2002). Post evaluation of physical planning experience of Ankara: 1957 Plan of Uybadin - Yücel Plan. Unpublished Master's Thesis, Middle East Technical University Department of City and Regional Planning, Ankara.

Keçiören'i Adeta Yeniden Yarattık. (2007). Retrieved March 20, 2014, from http://v3.arkitera.com/h23203-kecioren-i-adetayeniden-yarattik.html
Keyder, Ç. (1998). 1990'larda Türkiye'de modernleşmenin doğrultusu. In S. Bozdoğan and R. Kasaba (Eds.), Türkiye'de modernleşme ve ulusal kimlik (pp.29-42) . İstanbul: Tarih Vakfı Yurt Yayınları.

Keyder, Ç. (2005). Globalization and social exclusion in Istanbul. International Journal of Urban and Regional Research, 29(1), 124-134.

Keyman, F. and Koyuncu, B. (2005). Globalization, alternative modernities and the political economy of Turkey. Review of International Political Economy 12(1), 105-128.

Kuban, D. (2008). Selçuklu çağında Anadolu sanatı. İstanbul: Yapı Kredi Yayınları.

Kurtoğlu, A. (1998). Local politics and social networks in urban Turkey: The case of hemşehrilik in the Keçiören Municipality. Unpublished Doctoral Dissertation, Middle East Technical University, Department of Political Science and Public Administration, Ankara.

Kurtoğlu, A. (2004). Hemşehrilik ve şehirde siyaset: Keçiören örneği. İstanbul: İletişim.

Küçükerman, Ö. and Yücel, İ. (1993). Milli saraylardaki cam eserlerin 19. yüzyılda Türk cam sanayiinin gelişimine etkileri ve Ahmet Fethi Paşa. In T. Ínce (Ed.), Milli Saraylar 1993 (pp. 26-37). Ankara: TBMM Basımevi.

Lewcock, R. (1978). Architects, craftsman and builders: Materials and techniques In G. Michell (Ed.), Architecture of the Islamic world: Its history and social meaning (pp. 112-144). London: Thames and Hudson.

Lingard, B., and Christie, P. (2003). Leading theory: Bourdieu and the field of educational leadership. An introduction and overview to this special issue. International Journal of Leadership in Education: Theory and Practice, 6(4), 317-333.

Mahalle/Muhtar. (n.d.). Keçiören Belediyesi. Retrieved 20.03.2014, from http://www.kecioren.bel.tr/muhtarliklar. html

Mathieu, C. J. (1999). The history of the tiffany windows at the Erskine and American Church Montreal. Unpublished Master's Thesis, Concordia University, Montreal.

Pinarevli, M. (2005). A study on the urban/architectural transformations in Keçiören after 1990s. Unpublished Master's Thesis, Middle East Technical University Department of Architecture, Ankara.

Poyraz, U. (2011). Looking at the urban transformation project from the gecekondu dwellers' perspective: The case of Mamak. Unpublished Master's Thesis, Middle East Technical University The Program of Urban Policy Planning and Local Governments, Ankara.

Rahkonen, K. (2011). Bourdieu and Nitzche: Taste as struggle. In S. Susen and B. S. Turner (Eds.), The legacy of Pierre Bourdieu (pp. 125-144). London: Anthem Press. 
Rey, T. (2007). Bourdieu on religion: Imposing faith and legitimacy. London: Equinox Publishing.

Saylan, A. (2008). Karmaşıklık ve beğeni: Keçiören örneği. Ankara: Gazi Üniversitesi.

Simakoff, N. (1993). Islamic designs in color. New York: Dover Publications.

Susen, S. (2011). Bourdieu and Adorno on the transformation of culture in modern society: Towards a critical theory of cultural production. In S. Susen and B. S. Turner (Eds.), The legacy of Pierre Bourdieu (pp. 173-202). London: Anthem Press.

Şahin, S. Z. (2007). The politics of urban planning in Ankara between 1985 and 2005. Unpublished Doctoral Dissertation, Middle East Technical University, Department of Political Science And Public Administration, Ankara.

Şengül, H. T. (2001). Kentsel çelişki ve siyaset: Kapitalist kentleşme süreçleri üzerine yazılar. İstanbul: Demokrasi Kitaplı̆̆ı.

Şenyapılı, T. (2004). Barakadan gecekonduya: Ankara'da kentsel mekânın dönüşümü 1923-1960. İstanbul: İletişim Yayınları.

Tatar, D. (2012). The AKP'S delirious spaces: Enjoying the notions of construction and architecture in neoliberal Turkey. Unpublished Master's Thesis, Sabancı University Department of Sociology, Istanbul.

Tekeli, İ. (1982). Türkiye'de kentlesme yazıları başkent Ankara'nın öyküsü. Ankara: Turhan Kitabevi Yayınları.

Tekeli, İ. (2005). Kent tarihi yazımı konusunda yeni bir paradigma önerisi. In T. Şenyapılı (Ed.), Cumhuriyet'in Ankara'sı: Doç. Dr. Özcan Altaban'a armağan (pp. 3-21). Ankara: ODTÜ Geliştirme Vakfı.
Tekin, C.. and Oğuz, Z. (2013). Traces of birdhouse tradition in Anatolia. World Academy of Science, Engineering and Technology International Journal of Civil, Architectural Science and Engineering, 7(4), 186-192.

Tuçaltan, G. (2008). Dynamics of Urban Transformation via Improvement Plans for Ankara City. Unpublished Master's Thesis, Middle East Technical University, Master of Science in Urban Design, Ankara.

Tuğal, C. (2002). Islamism in Turkey: Beyond instrument and meaning. Economy and Society, 31(1), 85-111.

Tuğal, C. (2009). Passive revolution: Absorbing the islamic challenge to capitalism. Standford: Standford University Press.

Tuncer, O. C. (1986). Anadolu kümbetleri. Ankara: Güven Matbaasi.

Turan, M. (2007). Başkentin gecekonduları: Kentsel dönüşüm projelerinin arka bahçeleri. In A. Mengi (Ed.), Kent ve planlama- geçmişi korumak geleceği tasarlamak (pp. 390404). Ankara: İmge Kitabevi.

Uzun, C. N. (2005). Residential transformation of squatter settlements: Urban redevelopment projects in Ankara. Journal of Housing and the Built Environment, 20(2), 183-199.

Wacquant, L. (2011). Durkheim and Bourdieu: The common plinth and its cracks. In S. Susen and B. S. Turner (Eds.), The legacy of Pierre Bourdieu (pp. 91-110). London: Anthem Press.

Webb, J., Schirato, T. and Danaher, G. (2002). Understanding Bourdieu. London: Sage Publication.

Webster, H. (2011). Bourdieu for architects. New York: Routledge. 